\title{
Identification and Biosynthetic Characterization of Natural Aromatic Azoxy Products from Streptomyces chattanoogensis L10
}

\author{
Yuan-Yang Guo, ${ }^{\dagger}$ Han $\mathrm{Li}^{\dagger}{ }^{\dagger}$ Zhen-Xing Zhou, ${ }^{\dagger} \mathrm{Xu}-\mathrm{Ming} \mathrm{Mao},{ }^{\dagger} \mathrm{Yi} \mathrm{Tang}^{\perp}$ Xin \\ Chen, ${ }^{\dagger}$ Xin-Hang Jiang, ${ }^{\dagger}$ Yu Liu, ${ }^{\dagger}$ Hui Jiang, ${ }^{*}{ }^{\dagger}$ Yong-Quan $\mathrm{Li}^{*}{ }^{*}+$ \\ ${ }^{\dagger}$ Zhejiang Provincial Key Laboratory for Microbial Biochemistry and \\ Metabolism Engineering, Institute of Biochemistry, Zhejiang University, 866 \\ Yuhangtang Road, Hangzhou 310058, China \\ ${ }^{\perp}$ Department of Chemical and Biomolecular Engineering, University of California Los Angeles, \\ 402 Westwood Plaza, Los Angeles, California 90095, United States
}




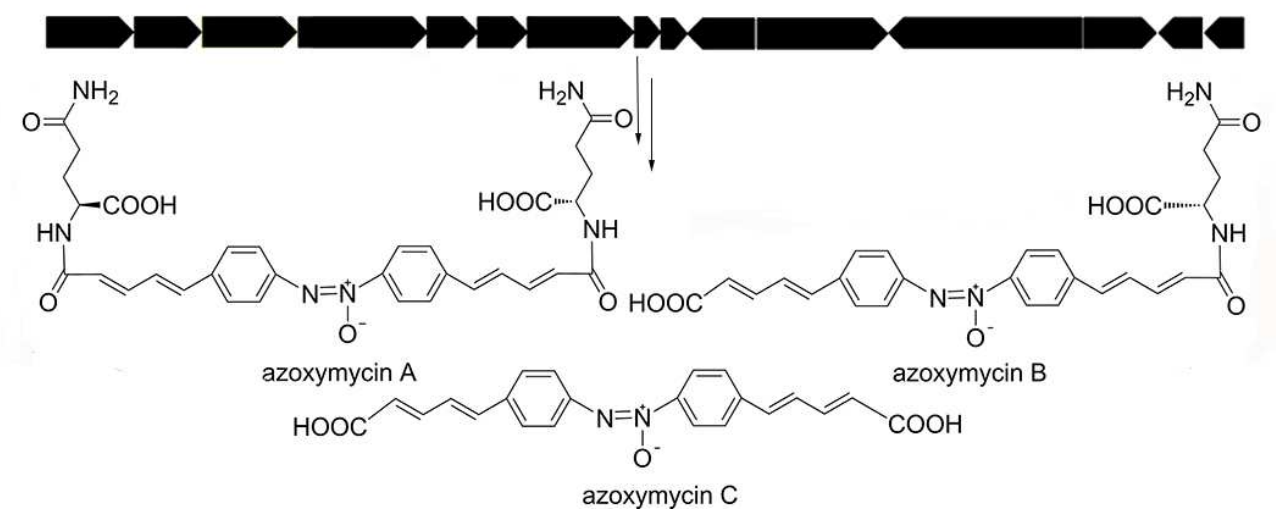




\section{Experimental section}

\section{General analytical procedures}

HPLC analysis was carried out on agilent 1260 infinity system with a DAD detector, column used was agilent ZORBAX SB-C18 $\left(5 \mu \mathrm{m}, 4.6^{*} 150 \mathrm{~mm}\right)$, mobile phase A was $0.1 \%$ TFA in water, mobile phase $\mathrm{B}$ was $0.1 \%$ TFA in methanol, flow rate was $1 \mathrm{~mL} \mathrm{~min}^{-1}$, during the analysis procedure mobile phase B was raised from $10 \%$ to $100 \%$ in $30 \mathrm{~min}$. Analysis of azoxymycins A, B and $C$ was carried out at $400 \mathrm{~nm}$, while compounds $A$ and $B$ were analyzed at $280 \mathrm{~nm}$.

HPLC analysis for photo and heat induced isomerizations (figures S37-S42) was also carried out on agilent 1260 infinity system with a DAD detector, column used was agilent poroshell 120 EC-C18 $(2.7 \mu \mathrm{m}, 3.0 * 50 \mathrm{~mm})$, mobile phase A was $0.1 \%$ TFA in water, mobile phase B was $0.1 \%$ TFA in acetonitrile, flow rate was $0.5 \mathrm{~mL} \mathrm{~min}^{-1}$, azoxymycins 1 and 2 were analyzed under $80 \%$ mobile phase $\mathrm{B}$ for 10 minutes at $280 \mathrm{~nm}$, while the azoxymycin 3 was analyzed under $100 \%$ mobile phase $B$ for 10 minutes at $280 \mathrm{~nm}$.

ESI-MS was conducted on a Thermo Finnigan LCQ Deca XP MAX system.

HR-TOF-MS was conducted on a AB TripleTOF 5600plus System (AB SCIEX, Framingham,USA).

NMR spectrums were tested with Bruker Advance 600 spectrometer. DMSO-D6 was used as the solvent of NMR test.

Rotation was tested on Jasco P-1000 polarimeter at 589nm.

\section{Azoxymycins producing condition}

Seed culture medium (YEME culture medium): yeast extract $3 \mathrm{~g} \mathrm{~L}^{-1}$, malt extract $3 \mathrm{~g} \mathrm{~L}^{-1}$, trypton $5 \mathrm{~g} \mathrm{~L}^{-1}$, glucose $10 \mathrm{~g} \mathrm{~L}^{-1}$.

Fermentation culture medium(optimized SMM culture medium): $10 \mathrm{~g} \mathrm{~L}^{-1}$ glucose, $7 \mathrm{~g} \mathrm{~L}^{-1} \mathrm{NH}_{4} \mathrm{NO}_{3}$, $1 \mathrm{~g} \mathrm{~L}^{-1} \mathrm{NaH}_{2} \mathrm{PO}_{4} \cdot 2 \mathrm{H}_{2} \mathrm{O}, 2.3 \mathrm{~g} \mathrm{~L}^{-1} \mathrm{Na}_{2} \mathrm{HPO}_{4} \cdot 12 \mathrm{H}_{2} \mathrm{O}, 0.1 \mathrm{~mL} \mathrm{~L}^{-1}$ trace element solution.

Streptomyces chattanoogensis L10 was inoculated into sterilized seed medium and incubated at $30^{\circ} \mathrm{C}, 200 \mathrm{rpm}$ for $24 \mathrm{~h}$, after that $0.1 \%$ of the seed culture was incubated to the optimized medium, and further incubation was carried out at $30^{\circ} \mathrm{C} 200 \mathrm{rpm}$ for $96 \mathrm{~h}$.

All the cultured medium used above should be sterilized at $115^{\circ} \mathrm{C}$ for $20 \mathrm{~min}$, and added with 5 to 20 glass beads, the medium should be less than $20 \%$ of the flask's maximum volume.

\section{Purification and physical description of azoxymycins.}

Fermentation broth of the S.chattanoogensis L10 was mixed with equal volume of methanol, and sustained for $12 \mathrm{~h}$, after that the mixture was centrifuged at 12000rpm for 10min, the supernate was collected and the residue was washed with water until no yellow color observed, the washing solution was centrifuged and combined with the supernate, and vacuumed dried at $40^{\circ} \mathrm{C}$. The dried residue was redissolved in DMSO and referred to HPLC separation.

Finally, $8.9 \mathrm{mg}$ azoxymycin A, $10.3 \mathrm{mg}$ azoxymycin $\mathrm{B}$, and $2.7 \mathrm{mg}$ azoxymycin C were isolated 
from $2 \mathrm{~L}$ culture.

Isotope labeled azoxymycins were purified with the same procedure. And $0.2 \mathrm{mg} 13 \mathrm{C}$ labeled azoxymycin $\mathrm{A}$, trace amount of ${ }^{13} \mathrm{C}$ labeled azoxymycin $\mathrm{B}$ and $\mathrm{C}$ were obtained from $100 \mathrm{~mL}{ }^{13} \mathrm{C}$ labeled SMM culture. $0.4 \mathrm{mg}{ }^{15} \mathrm{~N}$ labeled azoxymycin A, $0.2 \mathrm{mg}{ }^{15} \mathrm{~N}$ labeled azoxymycin $\mathrm{B}$, and trace amount of ${ }^{15} \mathrm{~N}$ labeled azoxymycin $\mathrm{C}$ were isolated from $200 \mathrm{~mL}{ }^{15} \mathrm{~N}$ labeled SMM culture. The azoxymycins A, B and C were yellow solid powder.

Azoxymycin $\mathrm{A}$ and $\mathrm{C}$ have a melting point above $350^{\circ} \mathrm{C}$ (decomposed while temperature above 350 ), and azoxymycin $\mathrm{B}$ have a melting point at $226^{\circ} \mathrm{C}$ 。

\section{Primer list and description}

GYY1: TCAACGTCGGCAAGTTCAAC

GYY2: GTGGTTGCCCATGAACTTGAG

GYY3: CCCCCTCACCTACCACTCA

GYY4: CCCAGGTGTCCCATGATCT

GYY5: cgcgecggtaccegtaccegaagtacaaggagaatcacgATTCCGGGGATCCGTCGACC

GYY6: ttccegggggtctgggtgtctgaaggttgggtctgggggTGTAGGCTGGAGCTGCTTC

GYY7: gcggttcacccccagggecgecgegaggacgtccagcaATTCCGGGGATCCGTCGACC

GYY8: cgaccggtgtcttggegagcttctcggtttcetgcgcggTGTAGGCTGGAGCTGCTTC

GYY9: ceggcggtcattctcagctttcggaattgtggagcaccgATTCCGGGGATCCGTCGACC

GYY10: cgagcgggeccgaggecgcegggtccegtctggaagtgcTGTAGGCTGGAGCTGCTTC

GYY11: GATCGTCAATCCTGCGTTCCA

GYY12: ATGTCGTCGAGCATCTCGTGA

GYY13: TGGCCGTGGTGCTCGTCAG

GYY14: CGGACGCCGATTCGAGGATCA

GYY15: TGGGTCGACGACACGCTGTTG

GYY16: CTTGTCAGACGCGGCAGTTGG

GYY17: ATTCCGGGGATCCGTCGACC

GYY18: TGTAGGCTGGAGCTGCTTC

GYY19: GCGAGCTTCTCGGTTTCCTG

GYY20: CCACACGATGGAGGAGCGCTA

GYY21: CCGCTCCCGAAGGATTCGTGC 


\section{GYY22: CGGCGGTCATTCTCAGCTTTC}

GYY1/GYY2 were a pair of primers for screening the upstream of azoxymycins biosynthetic gene cluster, PCR product length was 500bp.

GYY3/GYY4 were a pair of primers for screening the downstream of azoxymycins biosynthetic gene cluster, PCR product length was about 500bp.

GYY5/GYY6 were a pair of primers for replacing azoC gene with aac(3)IV gene.

GYY7/GYY8 were a pair of primers for replacing $a z o F G$ gene with $a a c(3) I V$ gene.

GYY9/GYY10 were a pair of primers for replacing $a z o J$ gene with $a a c(3) I V$ gene.

GYY11/GYY12 were a pair of primers located inside azoC gene. Wild type strain's PCR product length was about $550 \mathrm{bp}$, mutant strain should have no PCR product.

GYY13/GYY14 were a pair of primers located inside azoFG gene. Wild type strain's PCR product length was about $720 \mathrm{bp}$, mutant strain should have no PCR product.

GYY15/GYY16 were a pair of primers located inside azoJ gene. Wild type strain's PCR product length was about $710 \mathrm{bp}$, mutant strain should have no PCR product.

GYY17/GYY18 were a pair of primers for $a a c(3) I V$ gene test. Mutant strain's PCR product length was about $1200 \mathrm{bp}$, wild type strain should have no PCR product.

GYY19/GYY20 were a pair of primers located outside $a z o F G$ gene. Wild type strain's PCR product length was about 1850bp, Mutant strain's PCR product length should be about 1250bp.

GYY21/GYY22 were a pair of primers located outside azoJ gene. Wild type strain's PCR product length was about 1550bp, Mutant strain's PCR product length should be about 1300bp.

\section{Construction of $\Delta \mathrm{azoC}, \Delta \mathrm{azoFG}$ and $\Delta \mathrm{azoJ}$ mutant.}

First, a cosmid 36E1, which harbored the azoxymycins biosynthesis gene cluster, was screened out with PCR amplification using two primer pairs GYY1/GYY2 and GYY3/GYY4, Second, three disruption cassette $a a c(3) I V$ genes were individually PCR amplified by using primer pairs GYY5/GYY6, GYY7/GYY8 and GYY9/GYY10 from $\mathrm{pHY773,} \mathrm{with} \mathrm{the} \mathrm{resulting} \mathrm{product}$ carrying 39 ends with homology to the corresponding region of the $a z o C$ gene, $a z o F G$ gene and azoJ gene, respectively. Three PCR products were then individually introduced into $E$. coli BW25113 carrying pIJ790/36E1, and the transformed cells carrying mutagenized 36E1 were selected on LB agar containing apramycin. Three mutagenized 36E1 cosmids, in which the azoC gene, $a z o F G$ gene and $a z o J$ gene were replaced with $a a c(3) I V$, were designated AZO-C, AZO-EF, AZO-J and confirmed by PCR analysis using primer pairs GYY11/GYY12, GYY13/GYY14 and GYY15/GYY16, respectively. Third, AZO-C, AZO-EF, AZO-J were individually transformed into E. coli ET12567/pUZ8002 respectively. Finally, after conjugal transfer of AZO-C, AZO-EF, AZO-J individually from E. coli ET12567/pUZ8002 into S. chattanoogensis L10, the single-crossover exconjugants were obtained after selection for apramycin. The single-crossover exconjugants were then inoculated onto YMG plates for two rounds of nonselective growth. The double-crossover exconjugants were obtained after selection for apramycin-resistant and thiostrepton-sensitive colonies. The resulting mutants, in which azoC gene, $a z o F G$ gene and $a z o J$ 
gene were in-frame deleted, were designated $\triangle a z o C, \triangle a z o F G$ and $\triangle a z o J$, the $\triangle a z o F G$ and $\triangle a z o J$ confirmed by PCR analysis using primer pairs GYY19/GYY20 and GYY21/GYY22 respectively, and $\triangle a z o C$ was confirmed by PCR analysis using primer pairs GYY11/GYY12 and GYY17/GYY18.

Table S1: NMR data of azoxymycins A and B (in DMSO, $\delta$ value in ppm)

\begin{tabular}{|c|c|c|c|c|}
\hline No. & Azoxymycin A & & Azoxymycin B & \\
\hline & $\delta \mathrm{H}$ & $\delta \mathrm{C}$ & $\delta \mathrm{H}$ & $\delta \mathrm{C}$ \\
\hline 1 & - & $143.15, \mathrm{C}$ & - & 147.20, C \\
\hline $1^{\prime}$ & - & $146.75, \mathrm{C}$ & - & $143.33, \mathrm{C}$ \\
\hline 2,6 & $2 \mathrm{H}, 8.17, \mathrm{~d}, J=8.3 \mathrm{~Hz}$ & $125.69, \mathrm{CH}$ & $2 \mathrm{H}, 8.28, \mathrm{~d}, J=8.7 \mathrm{~Hz}$ & $122.68, \mathrm{CH}$ \\
\hline $2^{\prime}, 6^{\prime}$ & $2 \mathrm{H}, 8.26, \mathrm{~d}, J=8.4 \mathrm{~Hz}$ & $122.41, \mathrm{CH}$ & $2 \mathrm{H}, 8.19, \mathrm{~d}, J=8.6 \mathrm{~Hz}$ & $125.87, \mathrm{CH}$ \\
\hline 3,5 & $2 \mathrm{H}, 7.75, \mathrm{~d}, J=8.5 \mathrm{~Hz}$ & $127.38, \mathrm{CH}$ & $2 \mathrm{H}, 7.81, \mathrm{~d}, J=8.8 \mathrm{~Hz}$ & $127.86, \mathrm{CH}$ \\
\hline $3^{\prime}, 5^{\prime}$ & $2 \mathrm{H}, 7.81, \mathrm{~d}, J=8.5 \mathrm{~Hz}$ & $127.5, \mathrm{CH}$ & $2 \mathrm{H}, 7.77, \mathrm{~d}, J=8.8 \mathrm{~Hz}$ & 127.60, CH \\
\hline 4 & - & 137.78 & - & $139.79, \mathrm{C}$ \\
\hline $4^{\prime}$ & - & 139.97 & - & 137.97, C \\
\hline 7 & $7.04, \mathrm{~d}, J=14.5 \mathrm{~Hz}$ & $136.91, \mathrm{CH}$ & $7.06, \mathrm{~d}, J=14.6 \mathrm{~Hz}$ & $137.25, \mathrm{CH}$ \\
\hline $7^{\prime}$ & $7.10, \mathrm{~d}, J=14.2 \mathrm{~Hz}$ & $136.13, \mathrm{CH}$ & $7.20, \mathrm{~d}, J=15.6 \mathrm{~Hz}$ & $137.89, \mathrm{CH}$ \\
\hline 8 & $7.23, \mathrm{dd}, J=20.6,13.2 \mathrm{~Hz}$ & $128.72, \mathrm{CH}$ & $7.31, \mathrm{dd}, J=10.3,4.9 \mathrm{~Hz}$ & $129.54, \mathrm{CH}$ \\
\hline $8^{\prime}$ & $7.23, \mathrm{dd}, J=20.6,13.2 \mathrm{~Hz}$ & $129.78, \mathrm{CH}$ & $7.24, \mathrm{~m}$ & $128.86, \mathrm{CH}$ \\
\hline 9 & $7.23, \mathrm{dd}, J=20.6,13.2 \mathrm{~Hz}$ & $139.09, \mathrm{CH}$ & $7.26, \mathrm{~m}$ & $139.51, \mathrm{CH}$ \\
\hline $9^{\prime}$ & $7.23, \mathrm{dd}, J=20.6,13.2 \mathrm{~Hz}$ & $138.82, \mathrm{CH}$ & $7.39, \mathrm{dd}, J=14.9 \mathrm{~Hz}$ & $143.76, \mathrm{CH}$ \\
\hline 10 & $6.32, \mathrm{~d}, J=13.8 \mathrm{~Hz}$ & $126.25, \mathrm{CH}$ & $6.31, \mathrm{~d}, J=14.2 \mathrm{~Hz}$ & $126.06, \mathrm{CH}$ \\
\hline $10^{\prime}$ & $6.35, \mathrm{~d}, J=13.8 \mathrm{~Hz}$ & $126.86, \mathrm{CH}$ & $6.12, \mathrm{~d}, J=15.1 \mathrm{~Hz}$ & $123.82, \mathrm{CH}$ \\
\hline 11 & - & $164.73, \mathrm{C}$ & - & 165.09, C \\
\hline $11^{\prime}$ & - & $164.63, \mathrm{C}$ & - & $167.45, \mathrm{C}$ \\
\hline $12,12^{\prime}$ & $2 \mathrm{H}, 8.32, \mathrm{~s}$ & - & $8.43, \mathrm{~d}, J=7.7 \mathrm{~Hz}$ & - \\
\hline $13,13^{\prime}$ & $2 \mathrm{H}, 4.22, \mathrm{dd}, J=13 \cdot 0,7.7 \mathrm{~Hz}$ & $52.17, \mathrm{CH}$ & $4.27, \mathrm{~d}, J=4.5 \mathrm{~Hz}$ & $51.81, \mathrm{CH}$ \\
\hline $14,14^{\prime}$ & - & $173.53, \mathrm{C}$ & - & $167.45, \mathrm{C}$ \\
\hline $15,15^{\prime}$ & $\begin{array}{l}2 \mathrm{H}, 2.0, \mathrm{dt}, J=13.1,7.6 \mathrm{~Hz} \\
2 \mathrm{H}, 1.8, \mathrm{dt}, J=14.8,7.8 \mathrm{~Hz}\end{array}$ & $27.31, \mathrm{CH} 2$ & $\begin{array}{l}2.01, \mathrm{dd}, J=15.0,6.9 \mathrm{~Hz}, \\
1.8, \mathrm{dd}, J=15.6,8.9 \mathrm{~Hz}\end{array}$ & $26.96, \mathrm{CH} 2$ \\
\hline
\end{tabular}




\begin{tabular}{lllll}
\hline $16,16^{\prime}$ & $4 \mathrm{H}, 2.13, \mathrm{~m}$ & $31.45, \mathrm{CH} 2$ & $2 \mathrm{H}, 2.15, \mathrm{~m}$ & $31.42, \mathrm{CH} 2$ \\
$17,17^{\prime}$ & - & $173.53, \mathrm{C}$ & - & $173.55, \mathrm{C}$ \\
$18,18^{\prime}$ & $2 \mathrm{H}, 7.34, \mathrm{~s}, 2 \mathrm{H}, 6.75, \mathrm{~s}$ & - & $6.78, \mathrm{~s}, 7.31, \mathrm{~s}$ & - \\
\hline
\end{tabular}

Table S2. In silico annotation of the ORFs in the putative azoxymycin biosynthesis gene cluster

\begin{tabular}{|c|c|c|c|c|}
\hline Protein (GenBank & & Homolog in asu & Homolog in S. lydicus & Homolog in $S$. auratus \\
\hline Accession) & Predicted function & PKS(identity) & (identity) & (identity) \\
\hline \multicolumn{5}{|l|}{ AzoA（AKQ24641 } \\
\hline ) & esterase & & WP_052686964(99\%) & EJJ08104(84\%) \\
\hline AzoB(AKQ24640) & ketoreductase & AsuC7 (67\%) & WP_046924478(99\%) & EJJ08105(94\%) \\
\hline AzoC(AKQ24642) & $p$-aminobenzoate $\mathrm{N}$-oxidase & & WP_046924477(99\%) & EJJ08106(91\%) \\
\hline AzoD(AKQ24643) & $\begin{array}{l}\text { EmrB/QacA subfamily drug } \\
\text { resistance transporter }\end{array}$ & & WP_052686963(99\%) & EJJ08107(87\%) \\
\hline AzoE(AKQ24644) & $\mathrm{ABC}$ substrate binding protein & & WP_046924475(99\%) & EJJ08108(70\%) \\
\hline AzoF(AKQ24645) & $\begin{array}{l}\text { beta-ketosynthase, beta } \\
\text { subunit (CLF) }\end{array}$ & AsuC14 (41\%) & WP_052686962(99\%) & EJJ08109(78\%) \\
\hline AzoG(AKQ24646) & $\begin{array}{l}\text { beta-ketoacyl synthase, alpha } \\
\text { subunit }\end{array}$ & AsuC13 (34\%) & WP_046924473(99\%) & EJJ08110(89\%) \\
\hline AzoH(AKQ24647) & 3,4-AHBA carrier protein & AsuC12(34\%) & WP_046924472(99\%) & EJJ08111(91\%) \\
\hline AzoI(AKQ24648) & $\mathrm{KS} \mathrm{I/II} \mathrm{associated} \mathrm{ACP}$ & AsuC11 (34\%) & WP_046924471(99\%) & EJJ08112(88\%) \\
\hline AzoO(AKQ24654) & $\begin{array}{l}\text { 4'-phosphopantetheinyl } \\
\text { transferase }\end{array}$ & & WP_052686961(99\%) & EJJ08113(69\%) \\
\hline AzoJ(AKQ24649) & $\begin{array}{l}\text { 3,4-AHBA carboxyl group } \\
\text { adenylation }\end{array}$ & AsuA2 (41\%) & WP_046924470(99\%) & EJJ08114(86\%) \\
\hline AzoK(AKQ24650) & $p$-aminobenzoate synthase & & WP_046924469(99\%) & EJJ08115(90\%) \\
\hline AzoL(AKQ24651) & $\begin{array}{l}\text { 4-amino-4-deoxychorismate } \\
\text { lyase }\end{array}$ & & WP_046924468(99\%) & EJJ08116(82\%) \\
\hline AzoM(AKQ24652) & acyl dehydratase & $\operatorname{AsuC} 8(33 \%)$ & WP_046924467(99\%) & EJJ08117(88\%) \\
\hline AzoN(AKQ24653) & acyl dehydratase & AsuC9 (51\%) & WP_046924466(99\%) & EJJ08118(80\%) \\
\hline
\end{tabular}




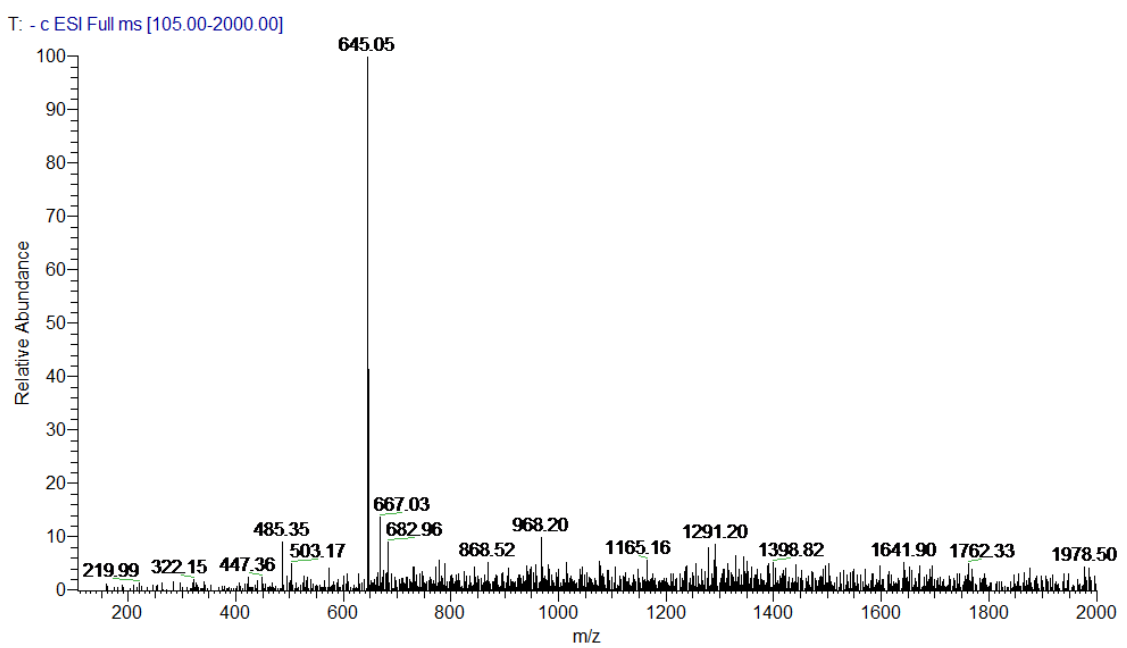

Figure S1. MS of azoxymycin A.

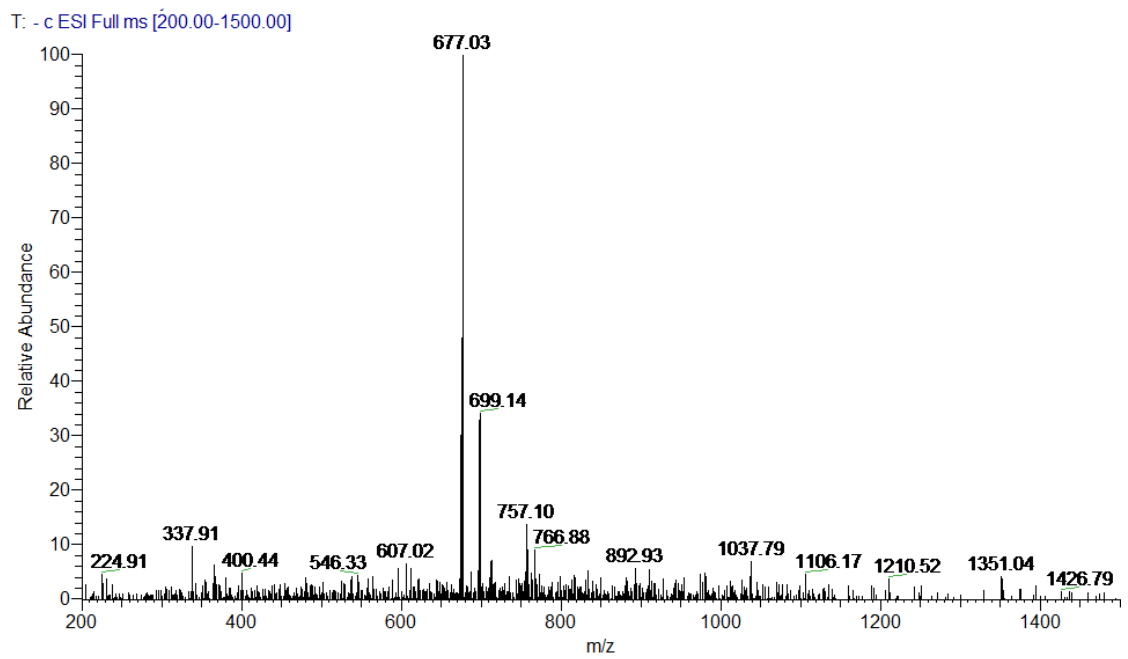

Figure S2. MS of ${ }^{13} \mathrm{C}$-labled azoxymycin A. 


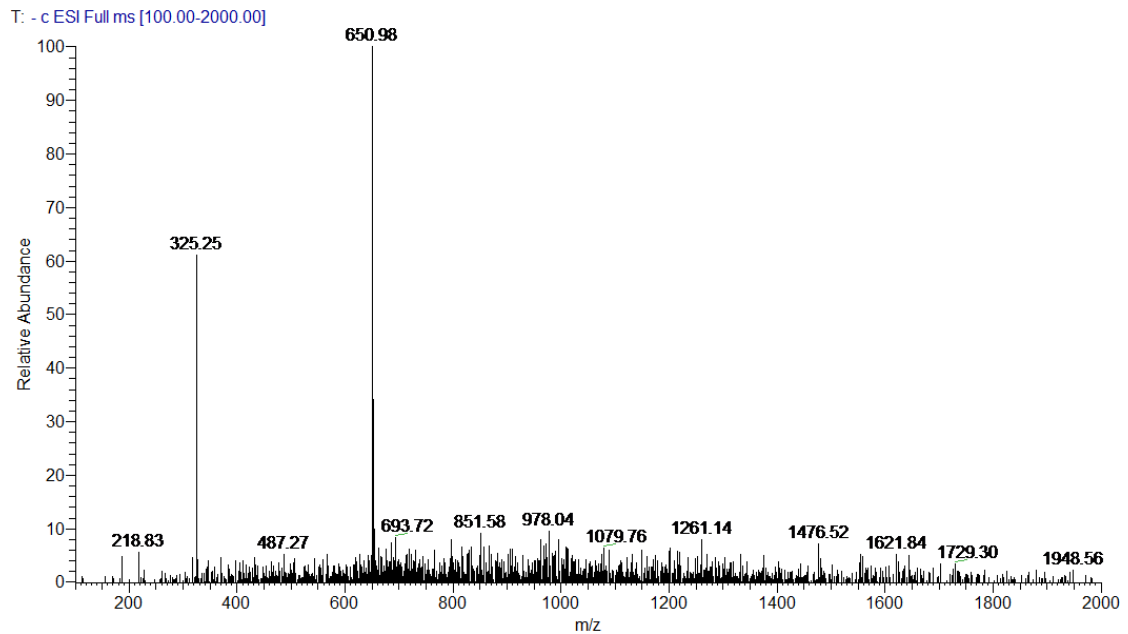

Figure S3. MS of ${ }^{15} \mathrm{~N}$-labled azoxymycin A.

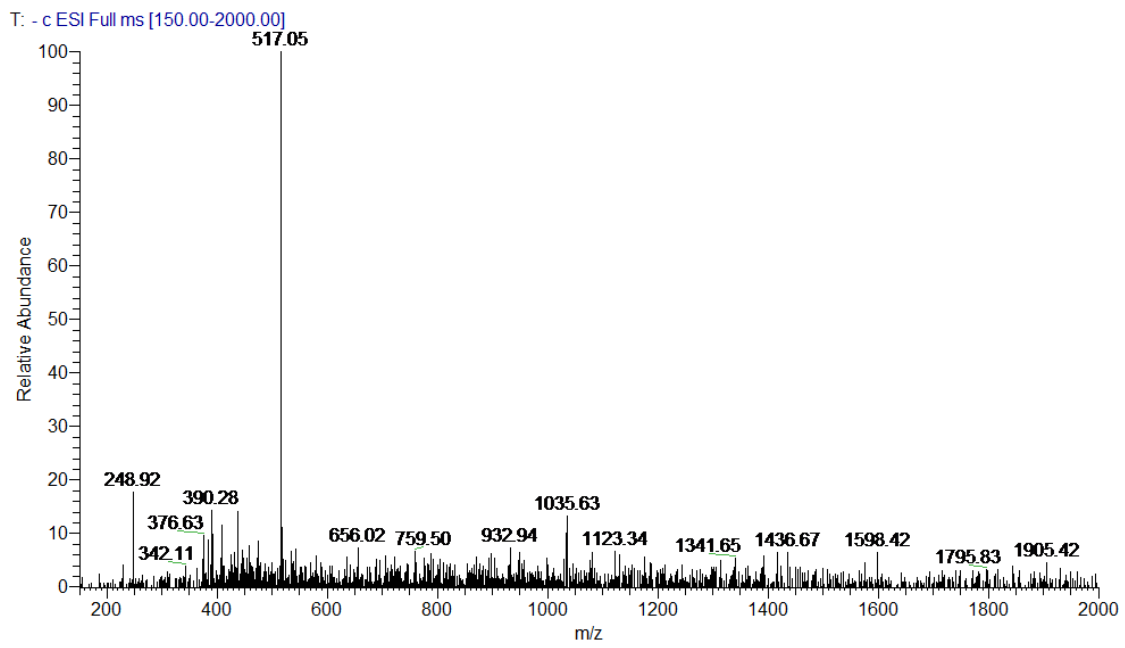

Figure S4. MS of azoxymycin B.

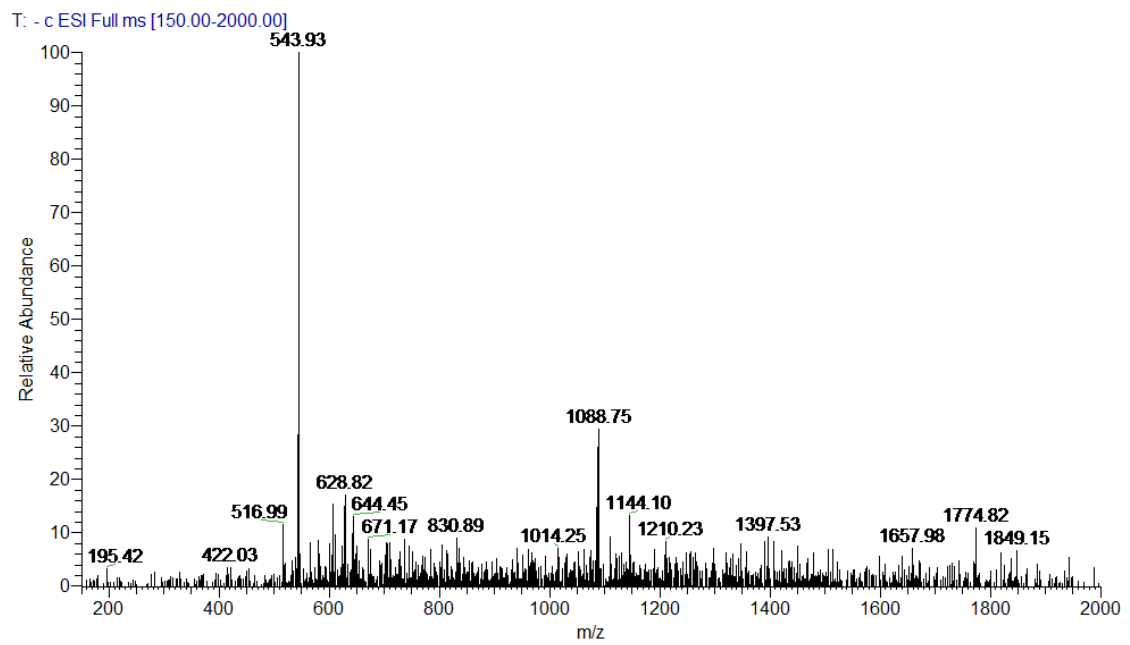


Figure S5. MS of ${ }^{13} \mathrm{C}$-labled azoxymycin B.

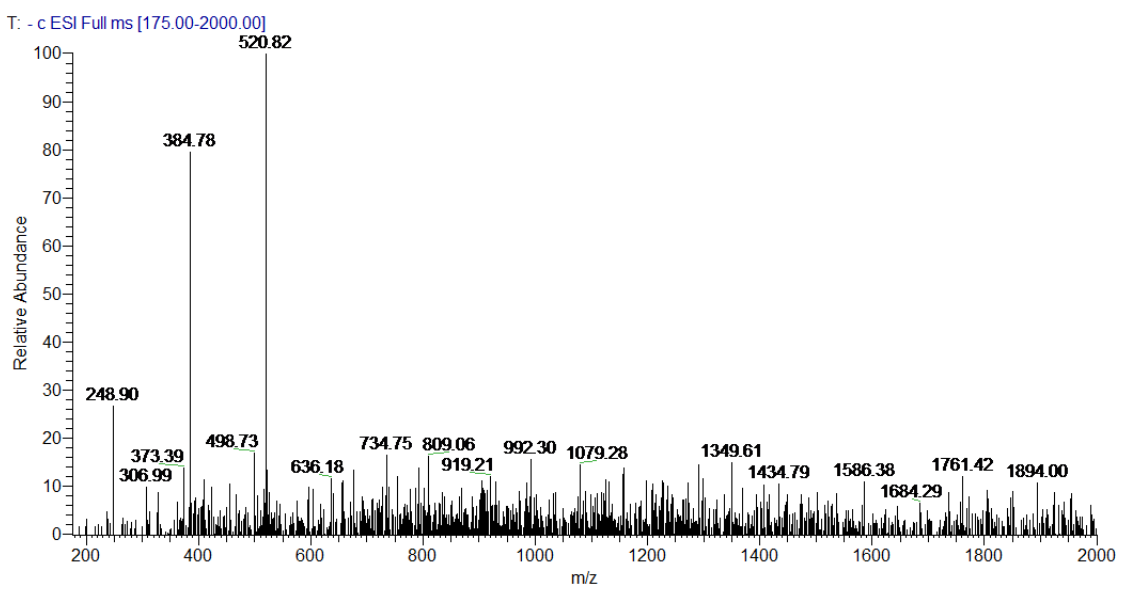

Figure S6. MS of ${ }^{15} \mathrm{~N}$-labled azoxymycin B.

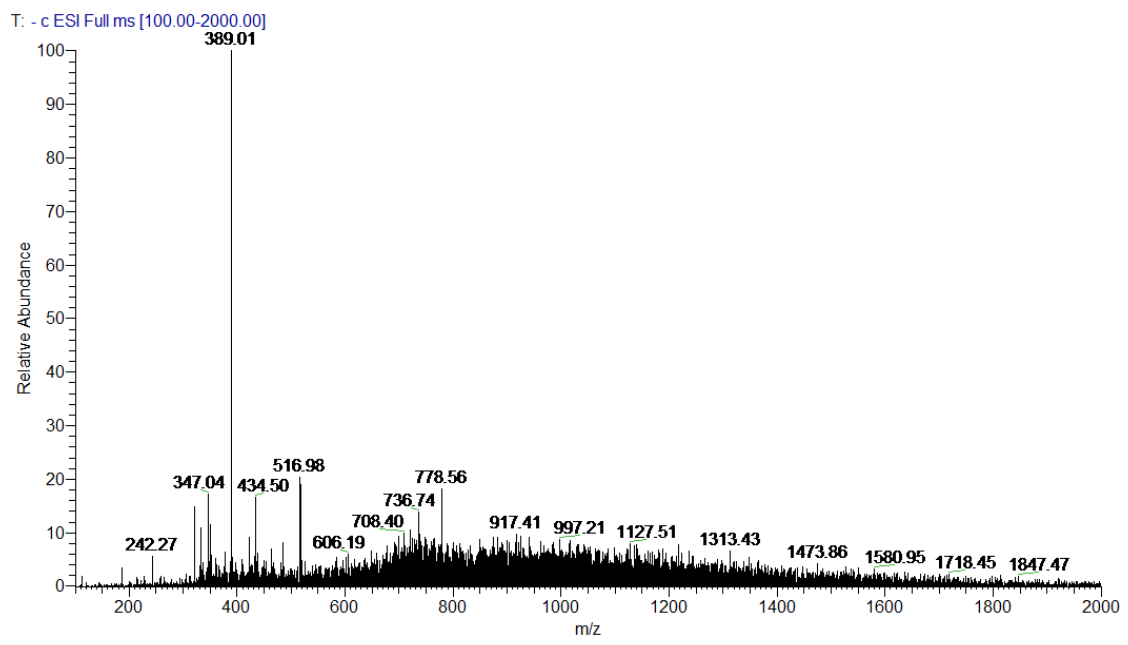

Figure S7. MS of azoxymycin C. 


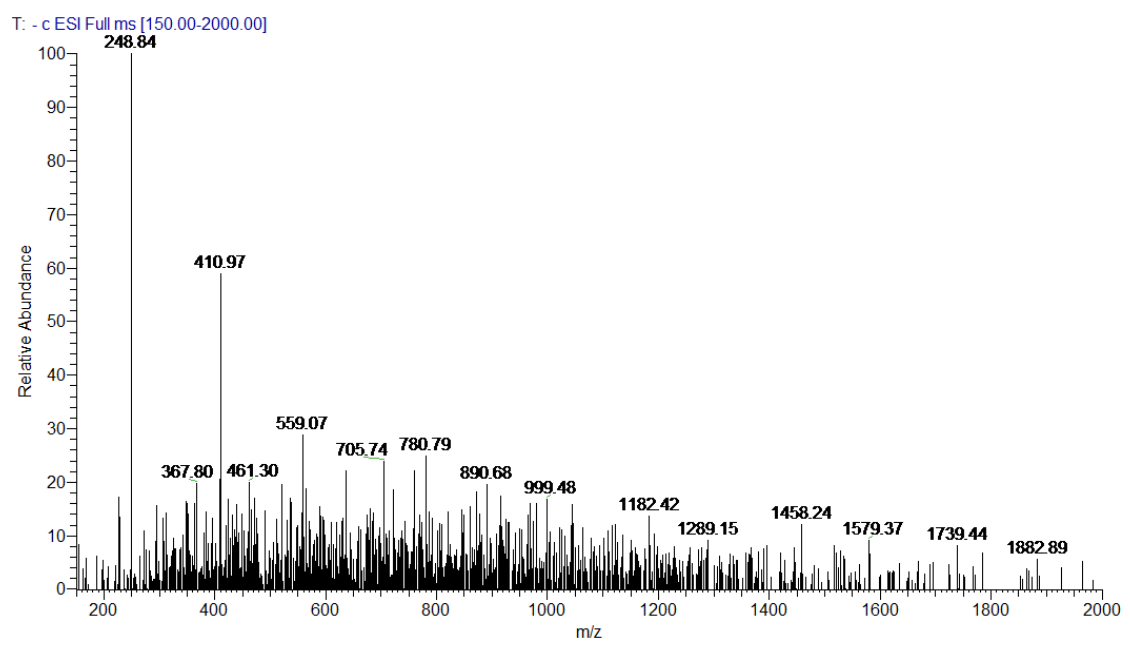

Figure S8.MS of ${ }^{13} \mathrm{C}$-labled azoxymycin C

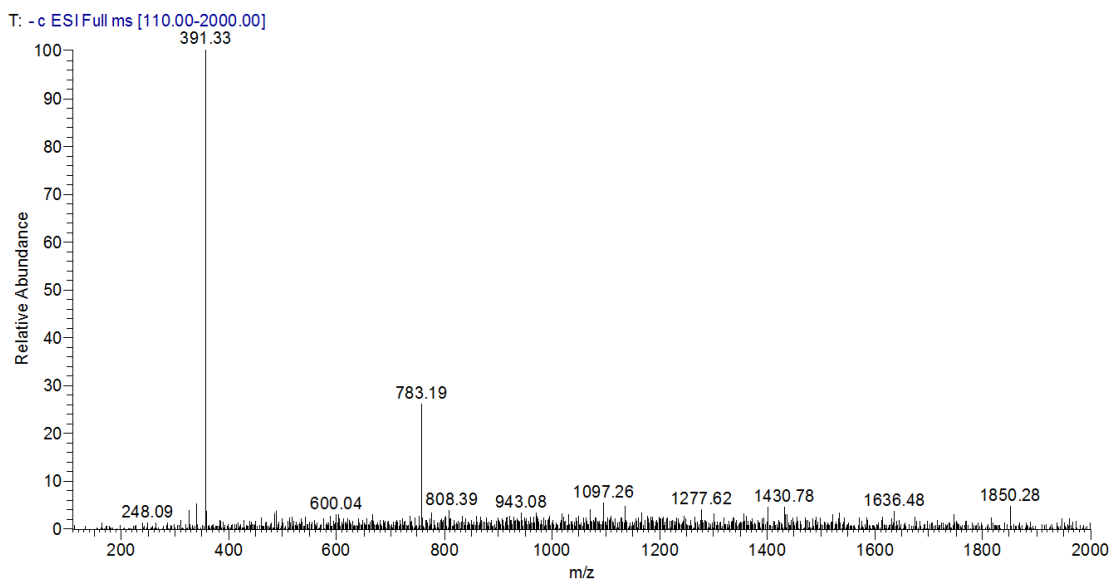

Figure S9.MS of ${ }^{15} \mathrm{~N}$-labled azoxymycin C

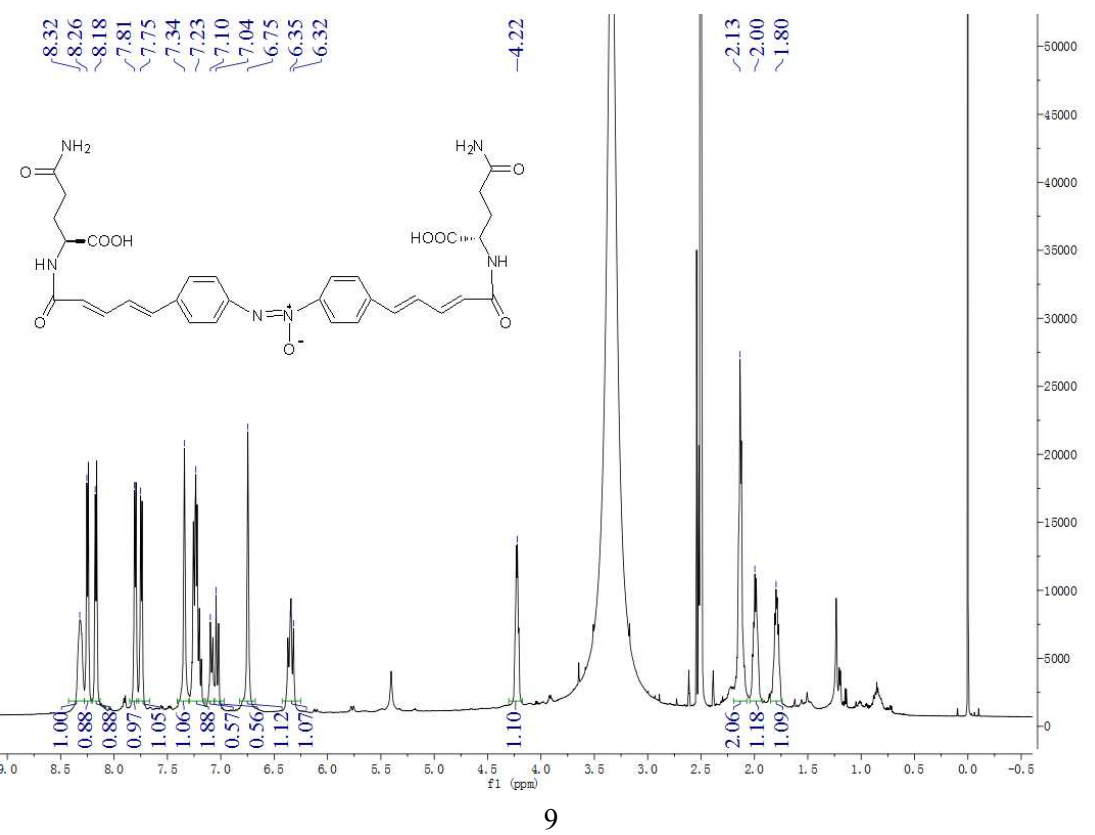


Figure S10. ${ }^{1} \mathrm{H}$ NMR spectrum of azoxymycin A.

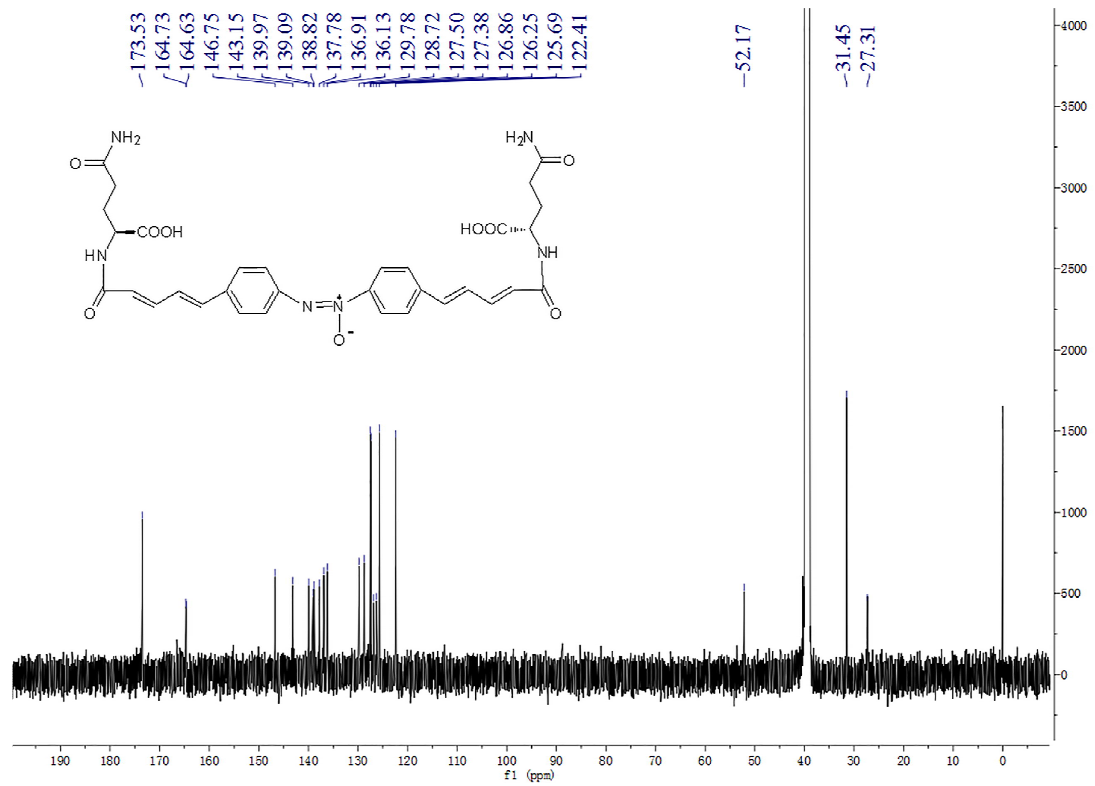

Figure S11. ${ }^{13} \mathrm{C}$ NMR spectrum of azoxymycin A.

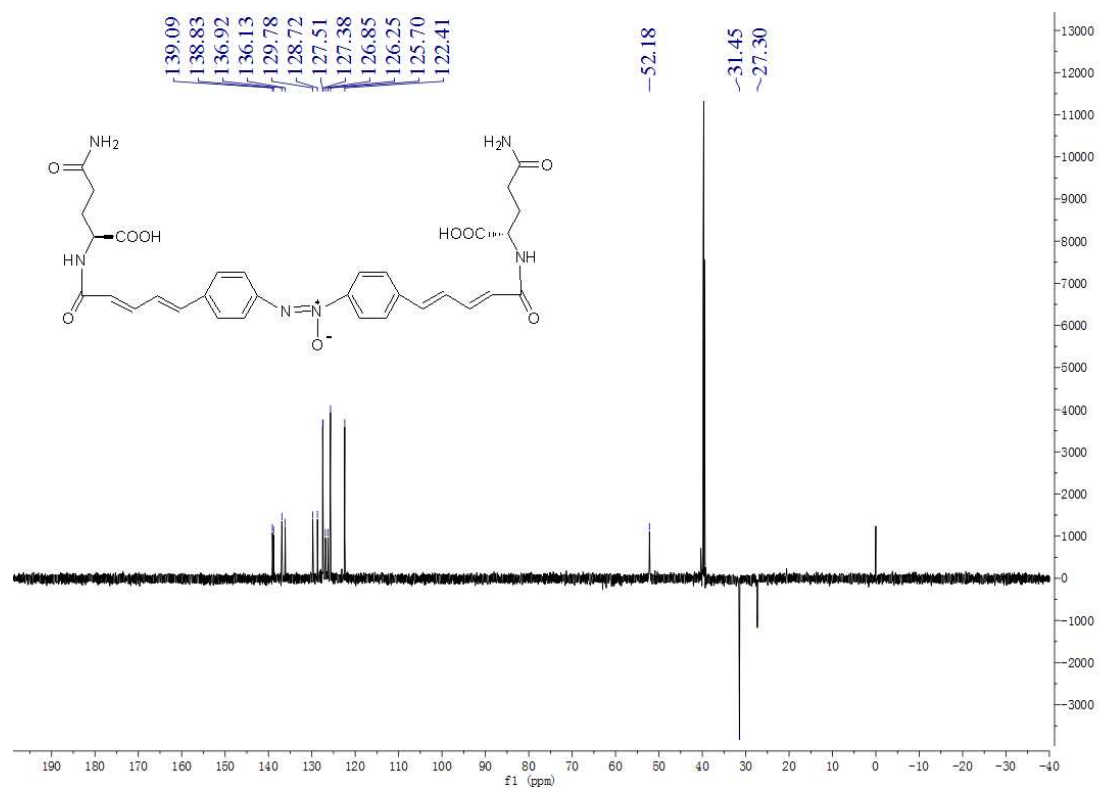

Figure S12. DEPT 135 spectrum of azoxymycin A. 


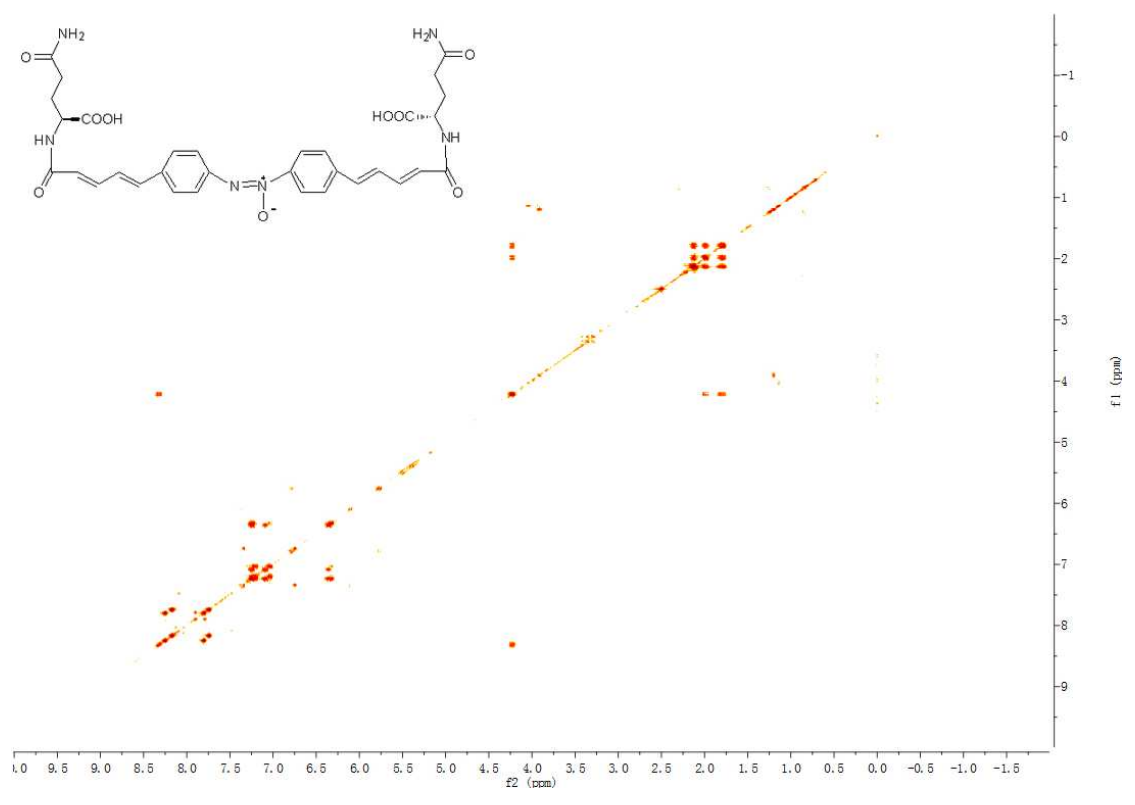

Figure S13. COSY spectrum of azoxymycin A.

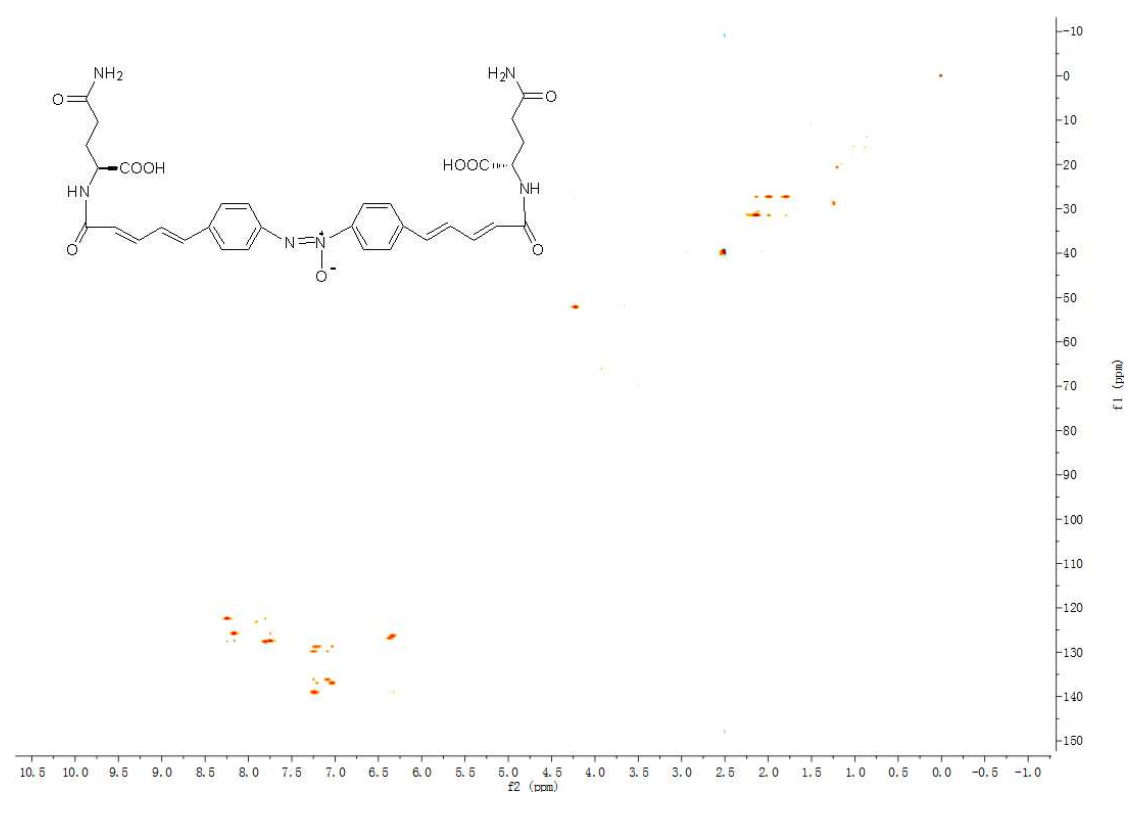

Figure S14. HSQC spectrum of azoxymycin A. 

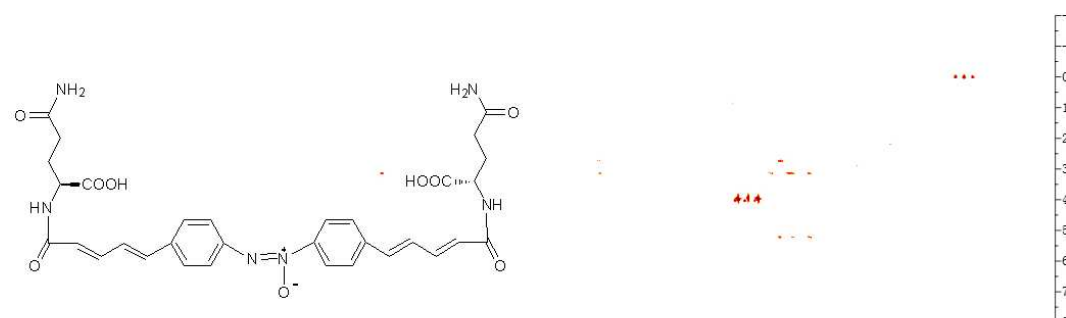

Figure S15. HMBC spectrum of azoxymycin A.

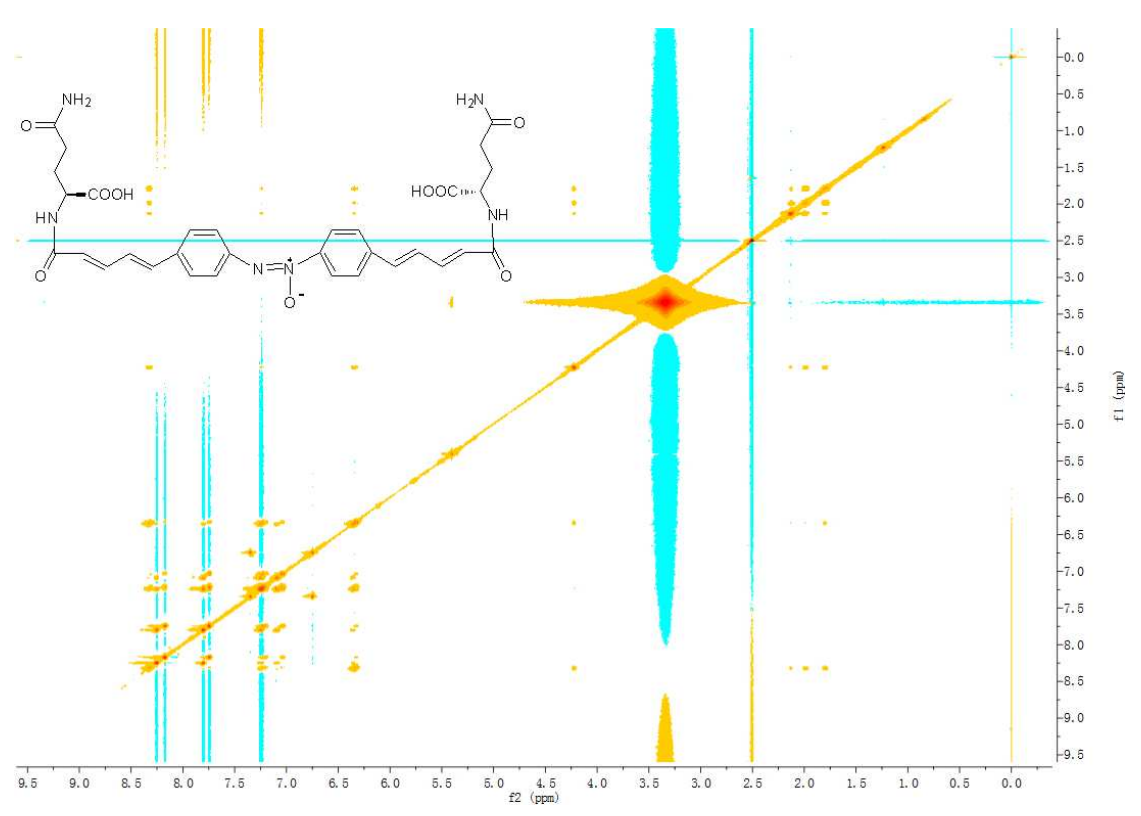

Figure S16. NOESY spectrum of azoxymycin A. 


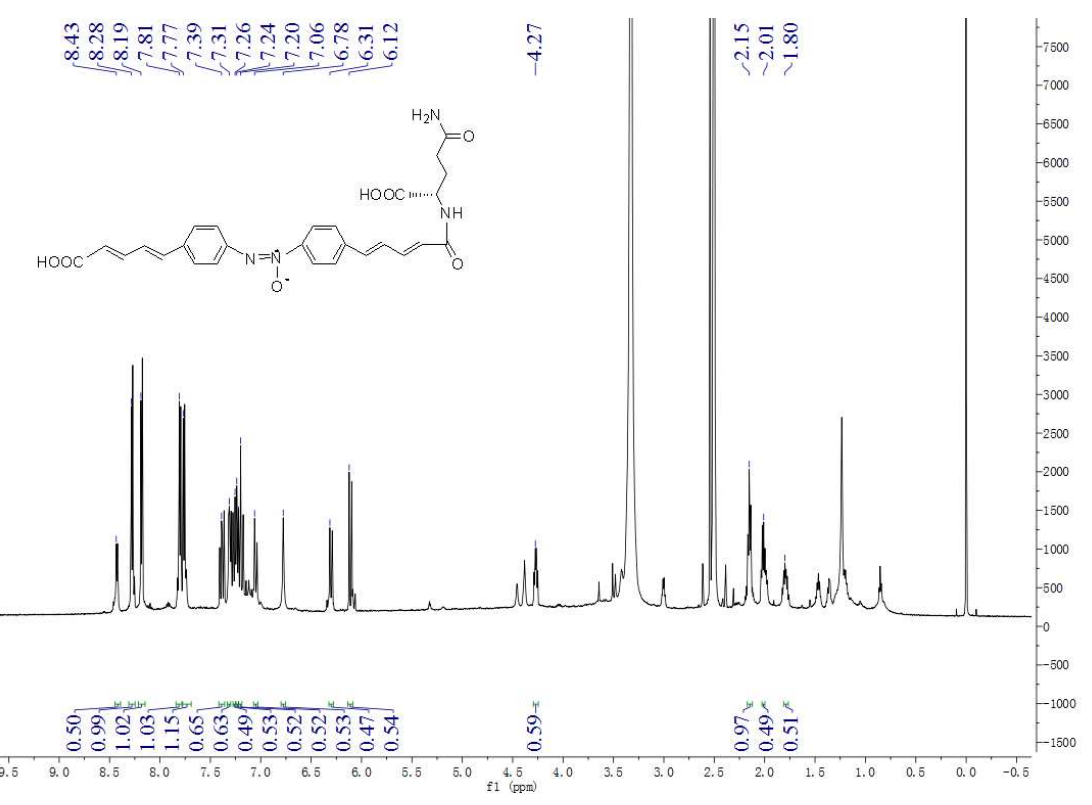

Figure S17. ${ }^{1}$ H NMR spectrum of azoxymycin B.

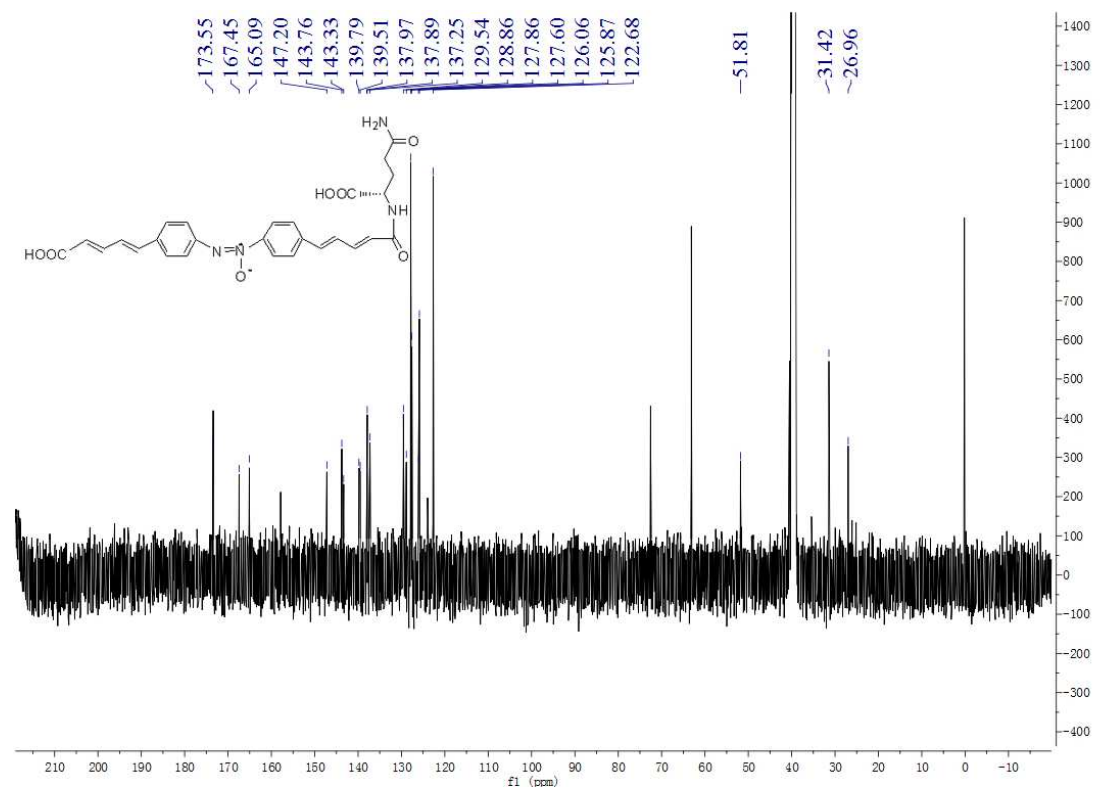

Figure S18. ${ }^{13} \mathrm{C}$ NMR spectrum of azoxymycin B. 


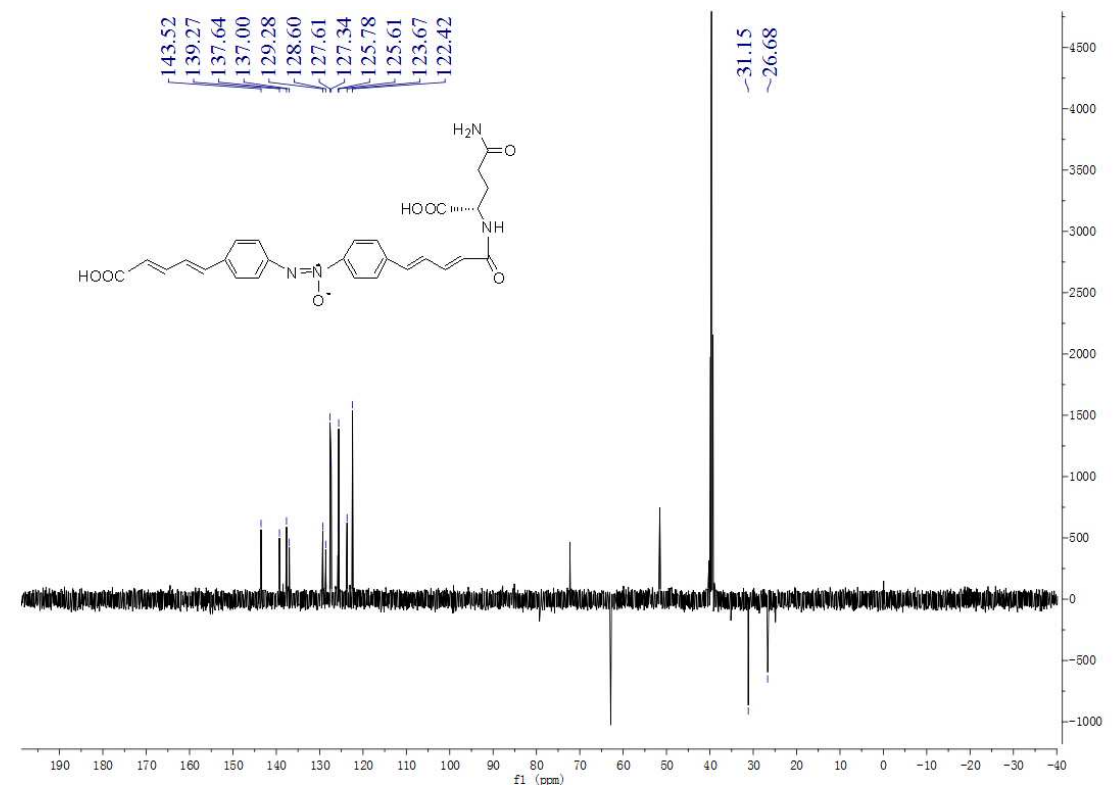

Figure S19. DEPT 135 spectrum of azoxymycin B.

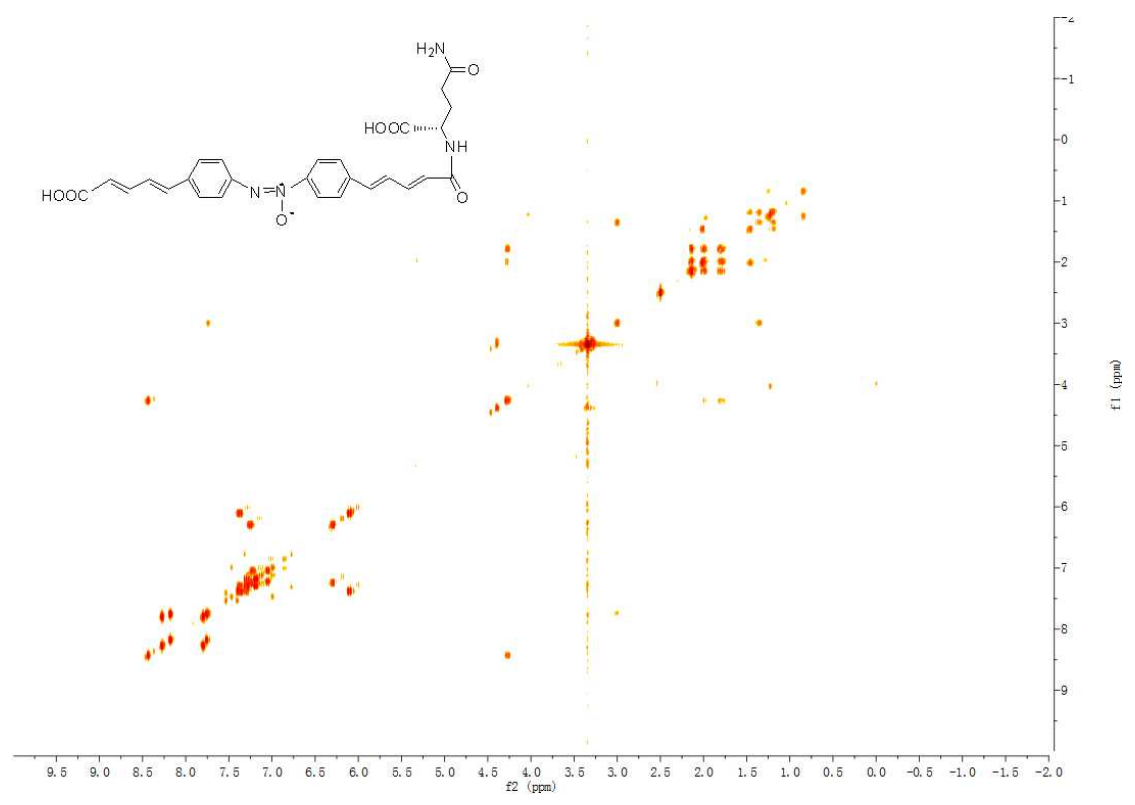

Figure S20. COSY spectrum of azoxymycin B. 


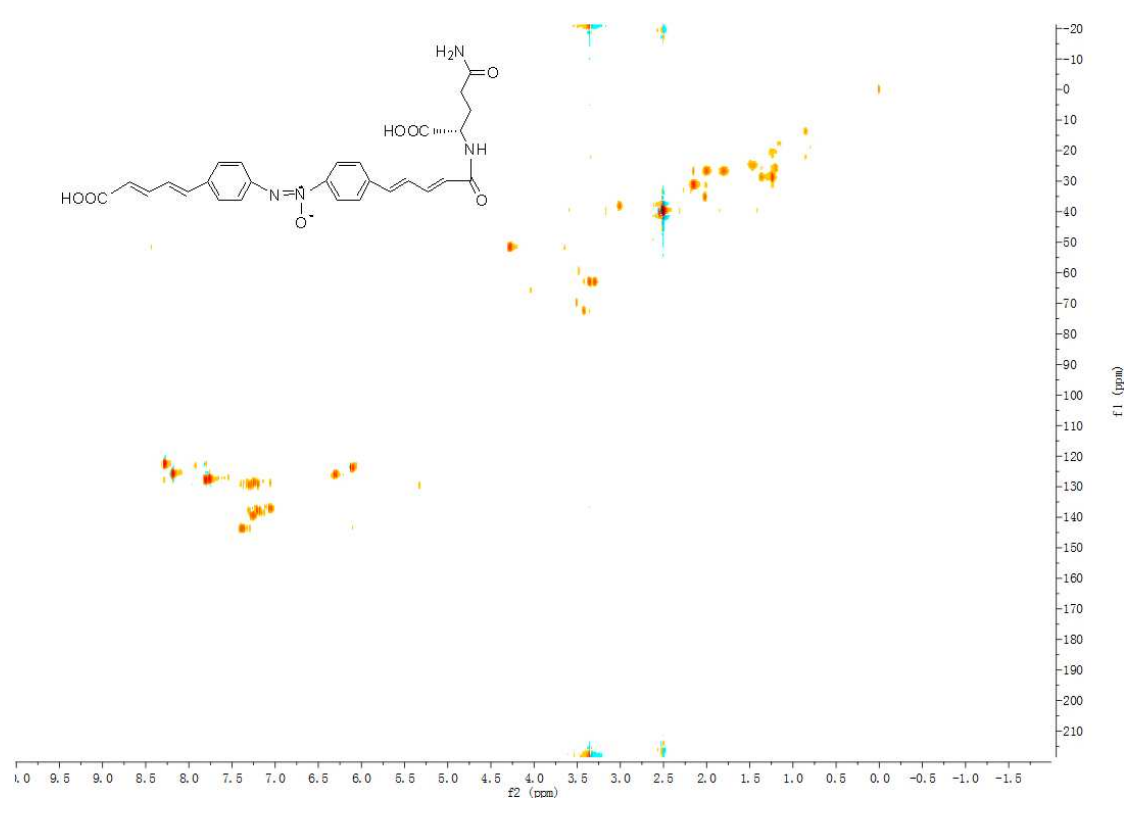

Figure S21. HSQC spectrum of azoxymycin B.

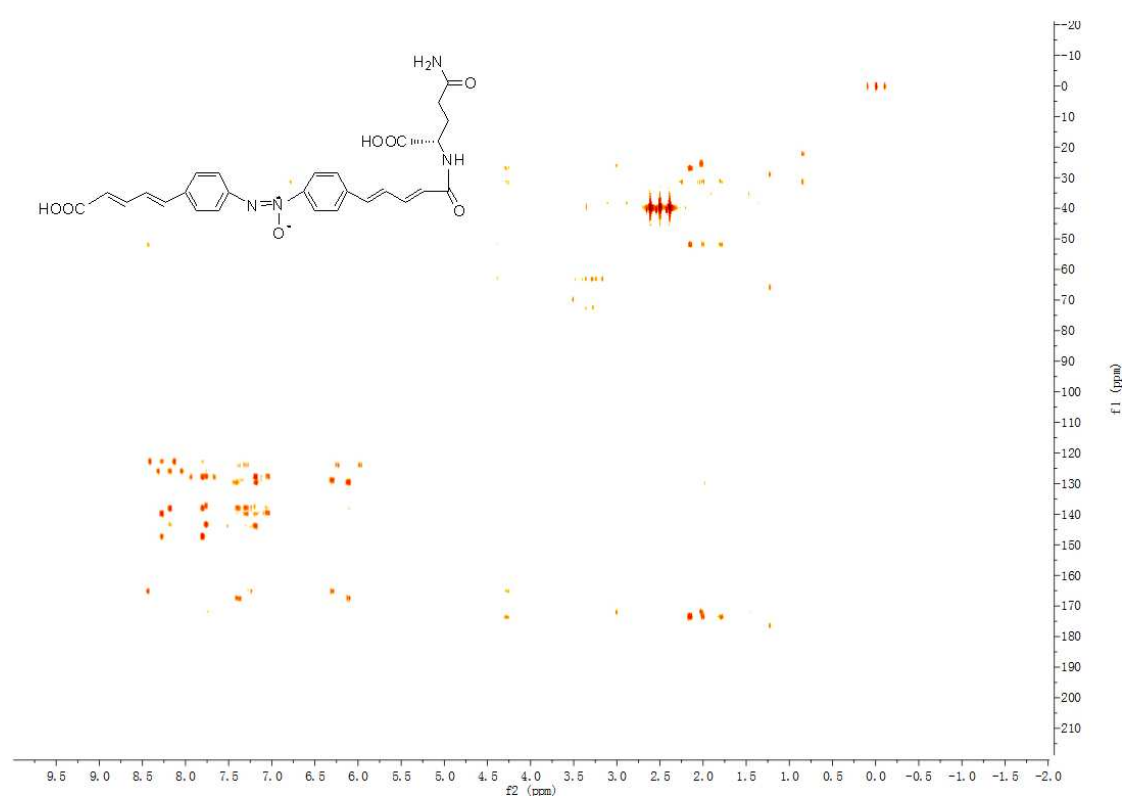

Figure S22. HMBC spectrum of azoxymycin B. 


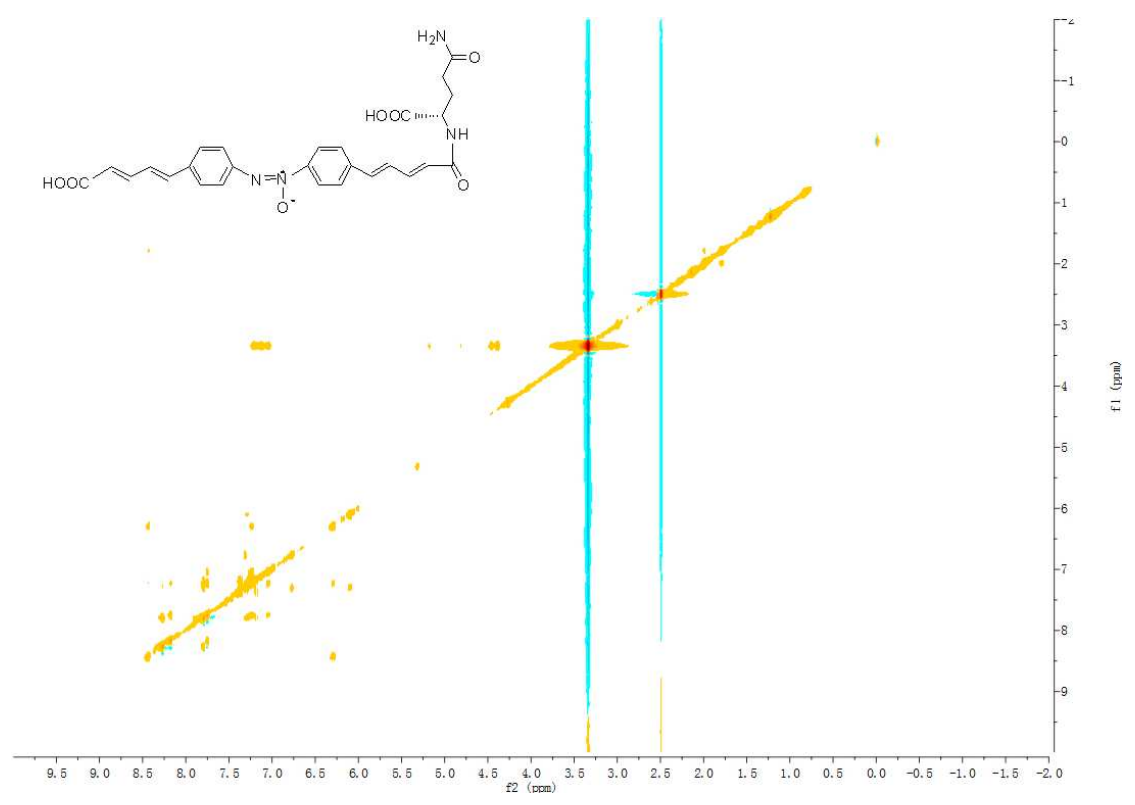

Figure S23. NOESY spectrum of azoxymycin B.

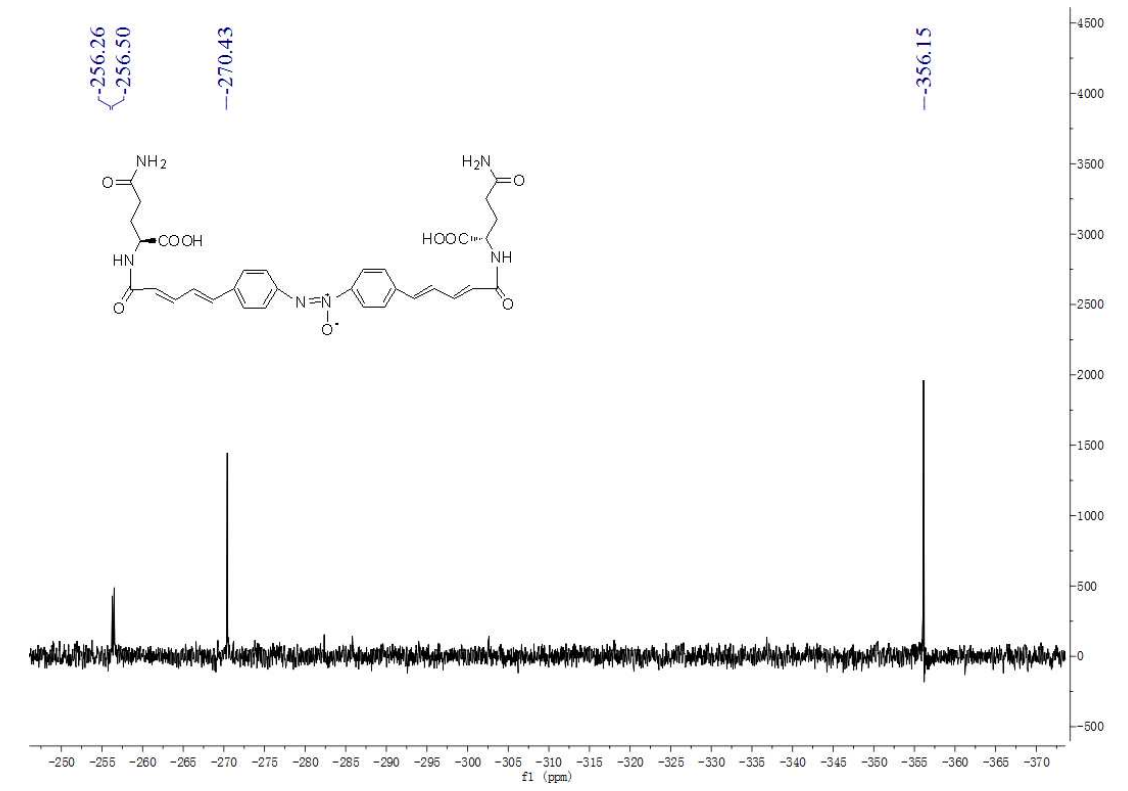

Figure S24. ${ }^{15} \mathrm{~N}$ spectrum of ${ }^{15} \mathrm{~N}$-labeled azoxymycin A. 


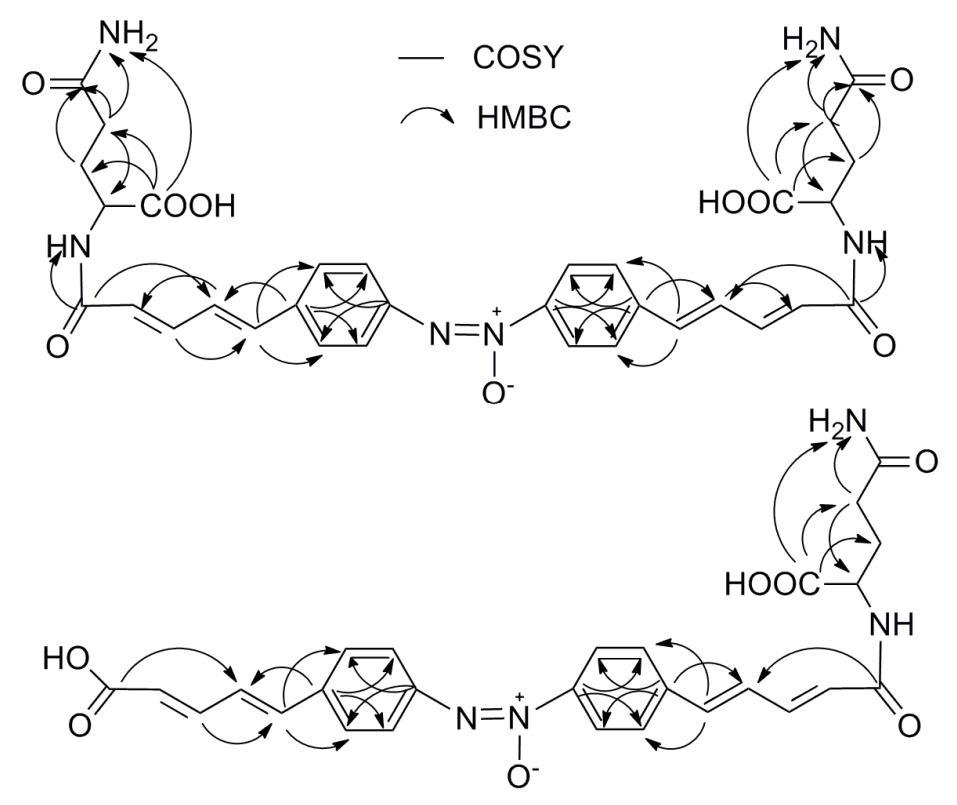

Figure S25. COSY and HMBC correlation of azoxymycins A and B.

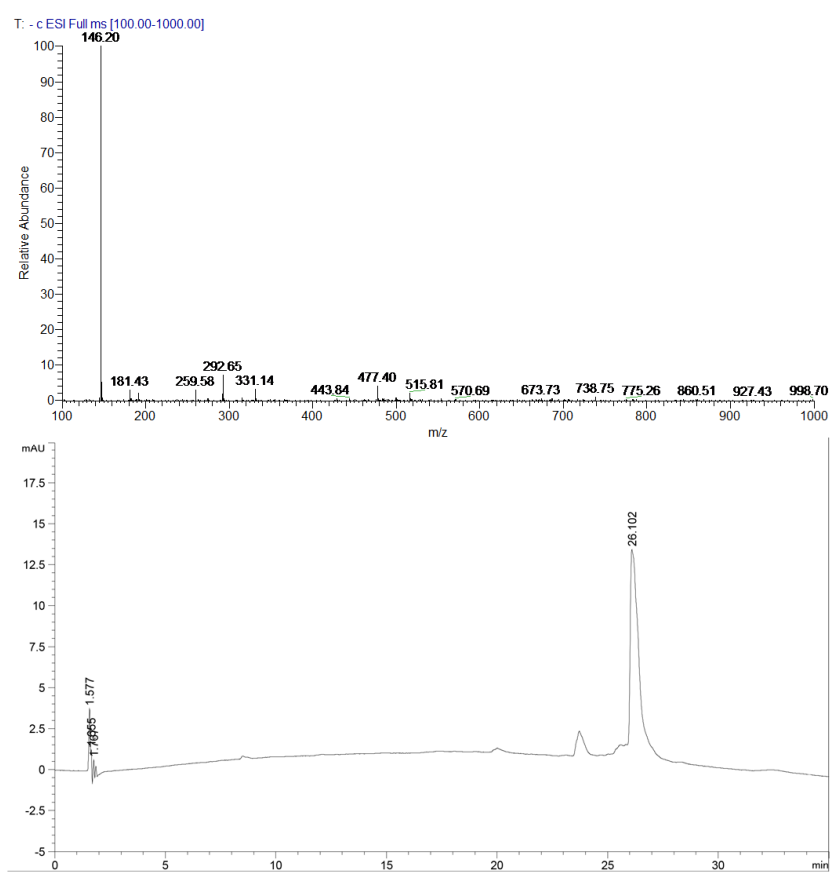

Figure S26. MS and HPLC spectrum of glutamate and azoxymycin C hydrolysed from azoxymycins A and B. 


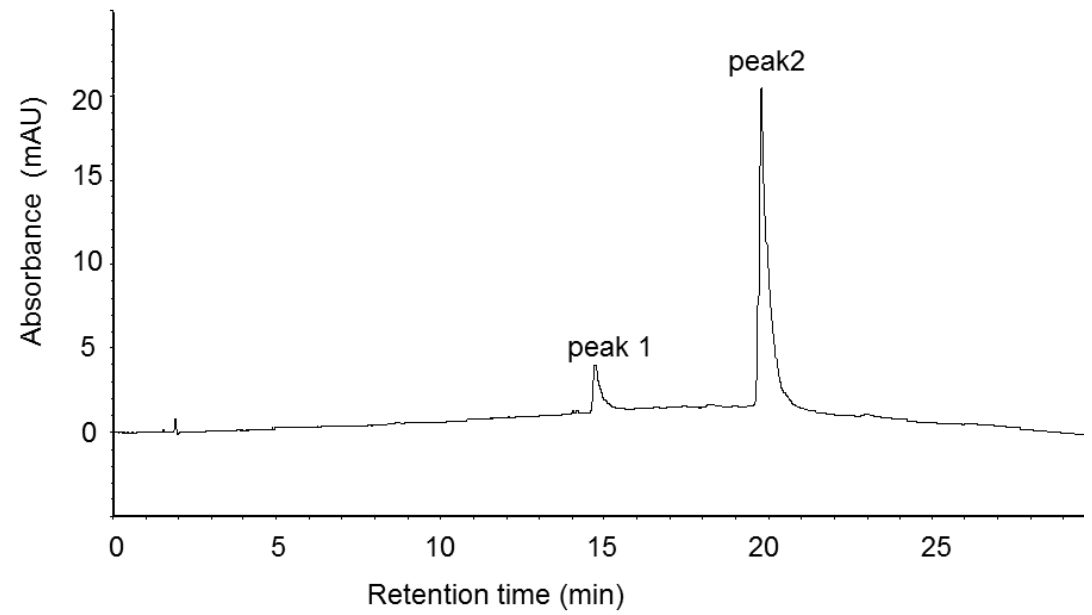

Figure S27. HPLC split of azoxymycin A(400nm)

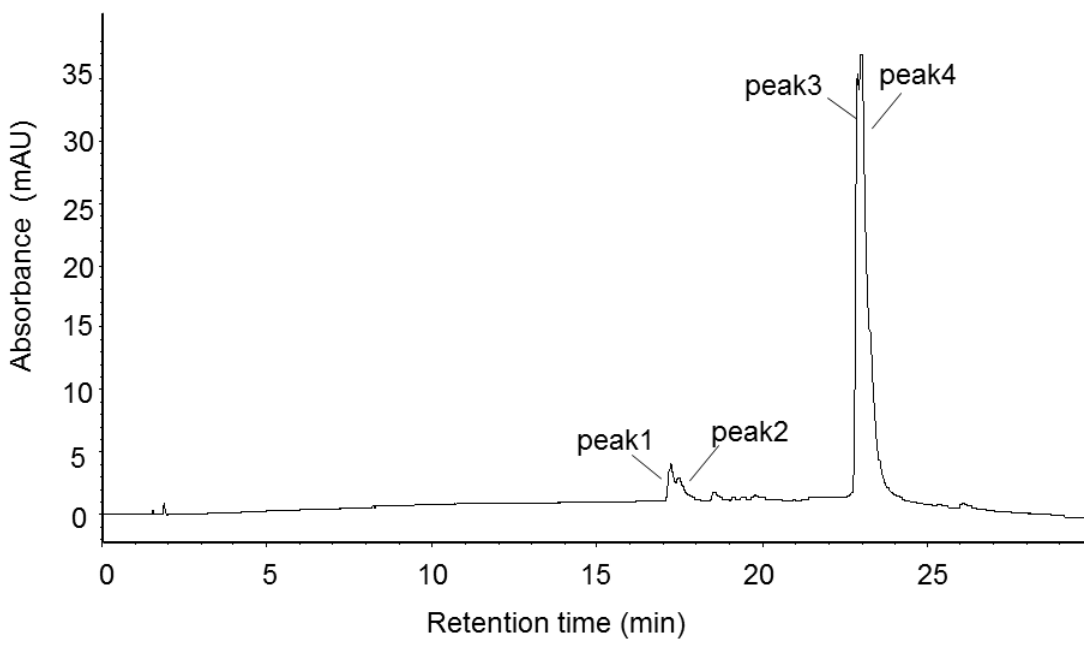

Figure S28. HPLC split of azoxymycin B(400nm)

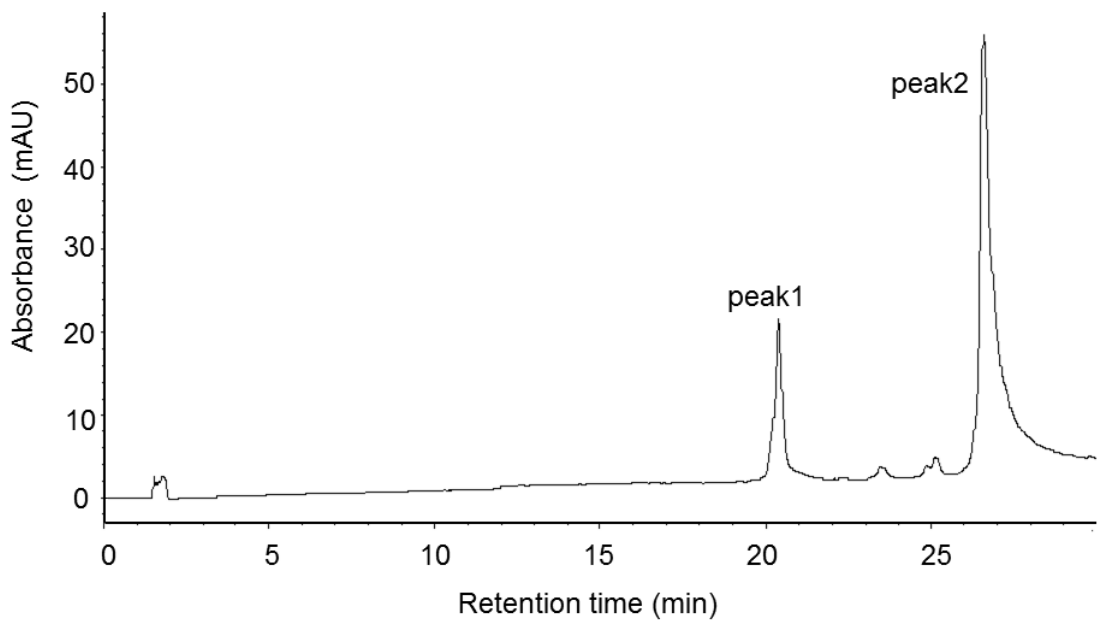


Figure S29. HPLC split of azoxymycin C(400nm)

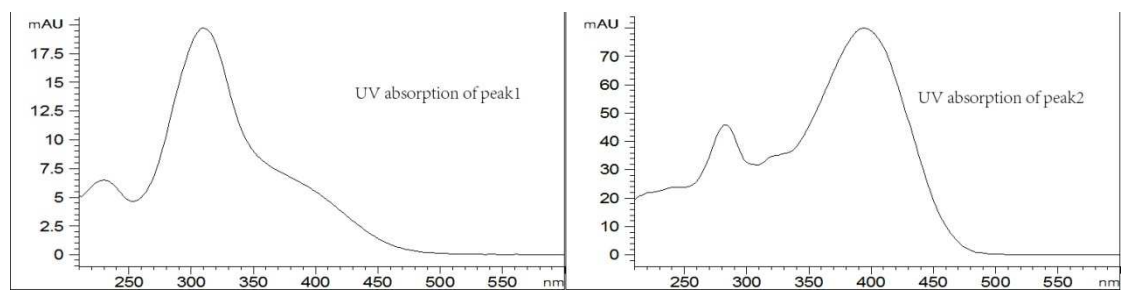

Figure S30. UV/Vis spectrums of azoxymycin A.

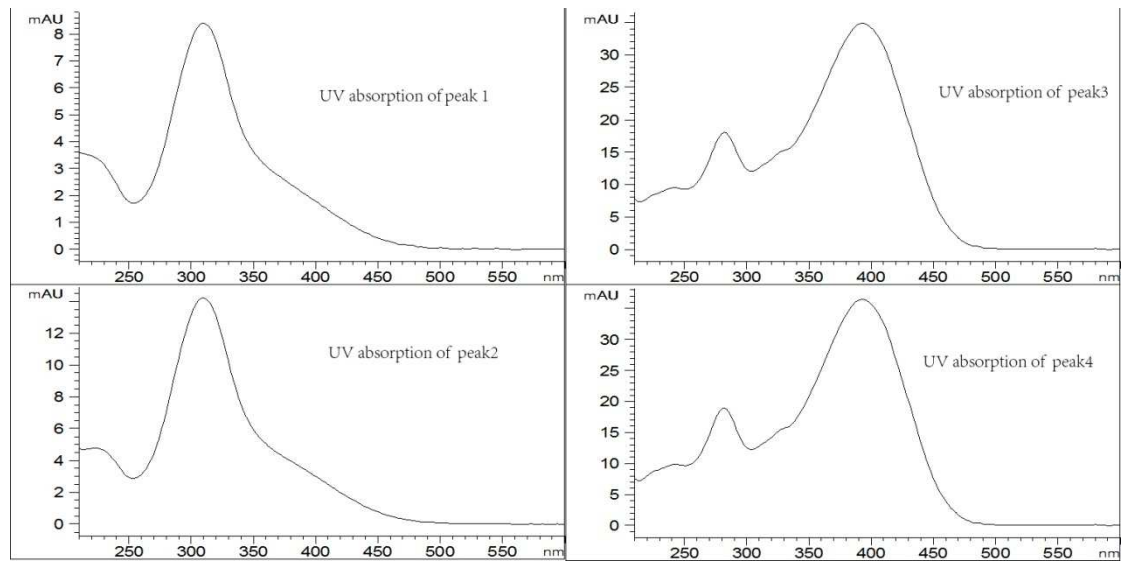

Figure S31. UV/Vis spectrums of azoxymycin B.
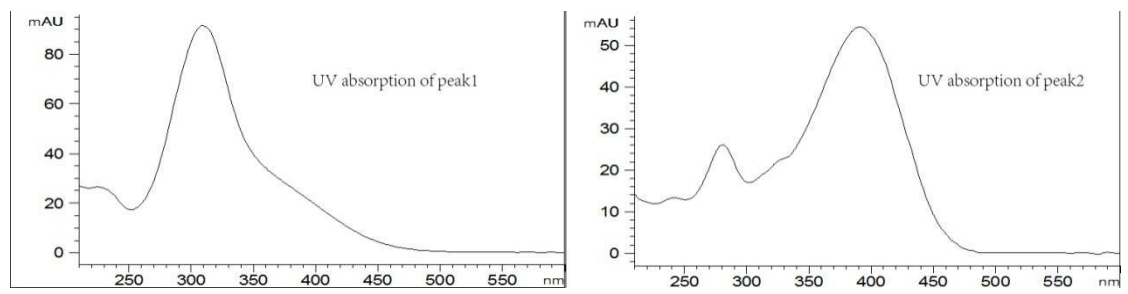

Figure S32. UV/Vis spectrums of azoxymycin C. 


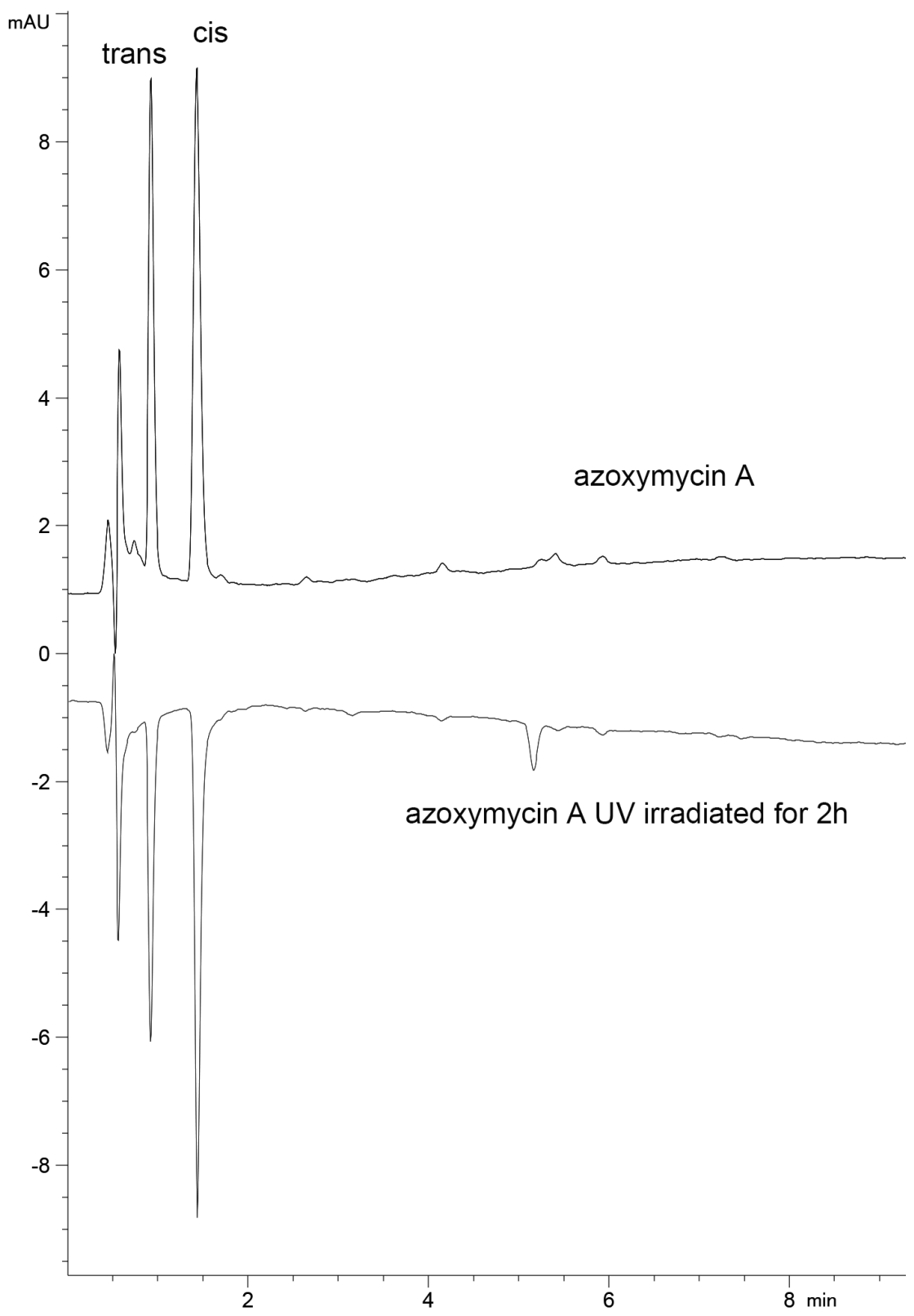

Figure S33. UV induced trans-cis isomerization of azoxymycin A. 


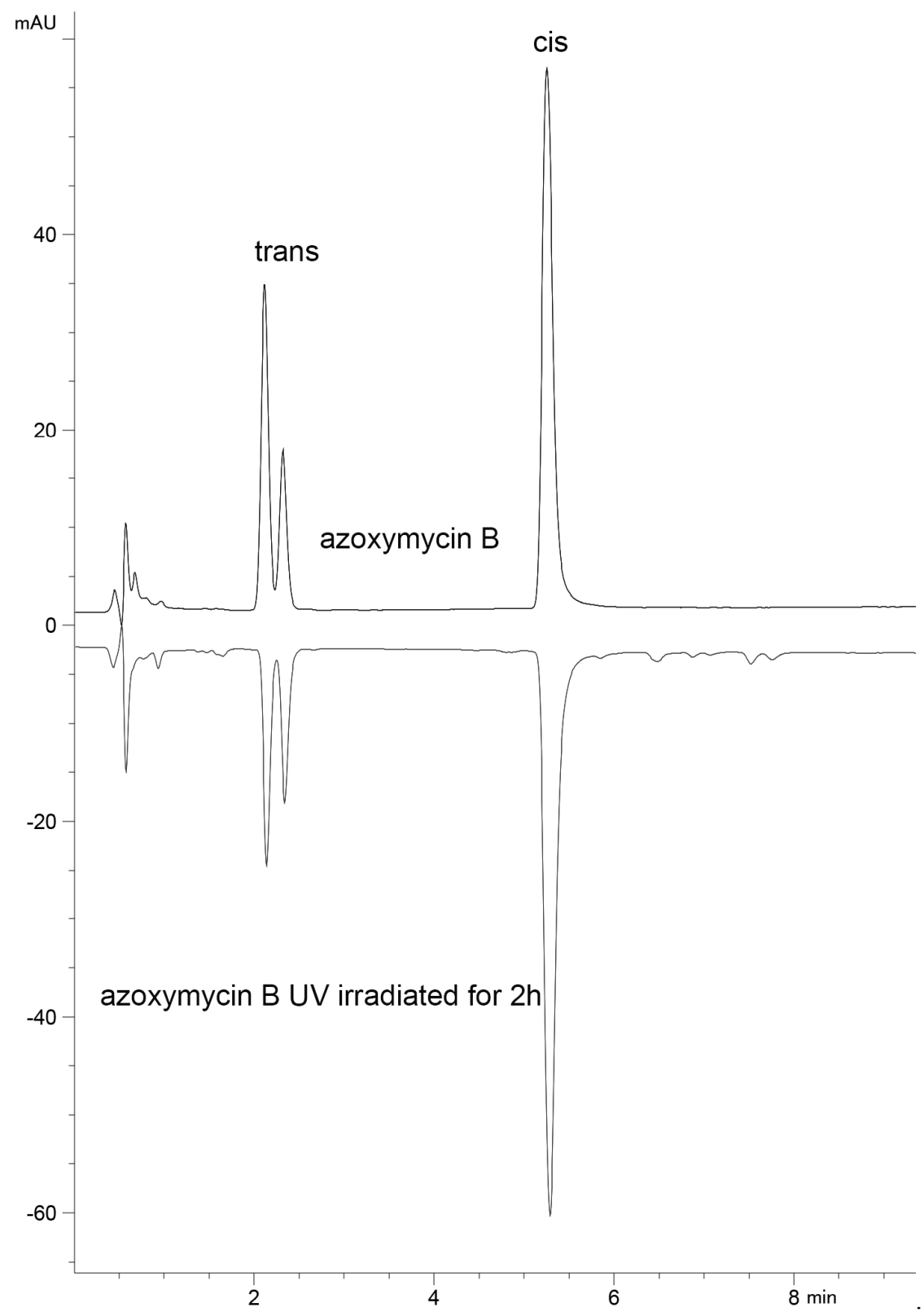

Figure S34. UV induced trans-cis isomerization of azoxymycin B. 


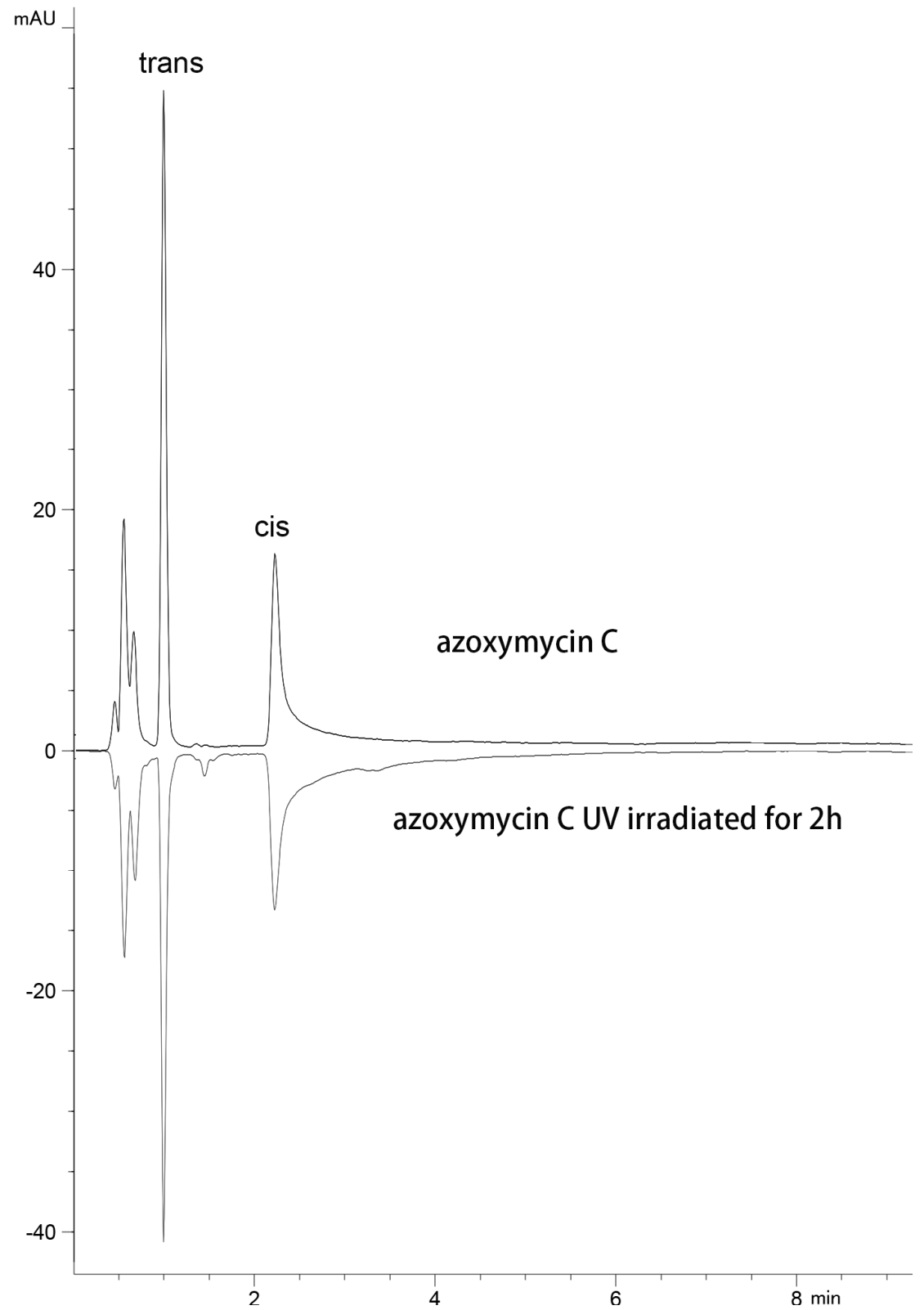

Figure S35. UV induced trans-cis isomerization of azoxymycin C. 


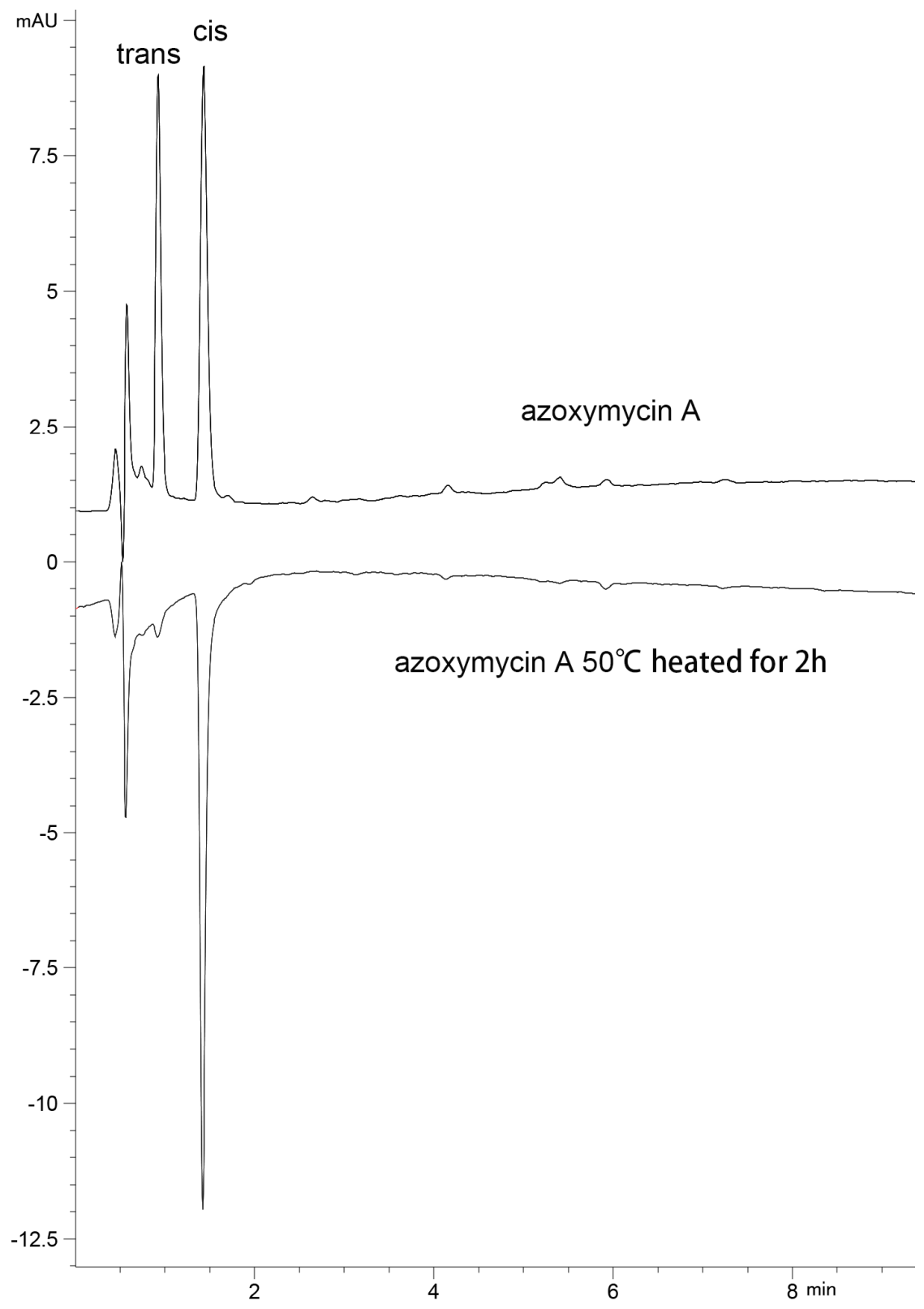

Figure S36. Heat induced trans-cis isomerization of azoxymycin A. 


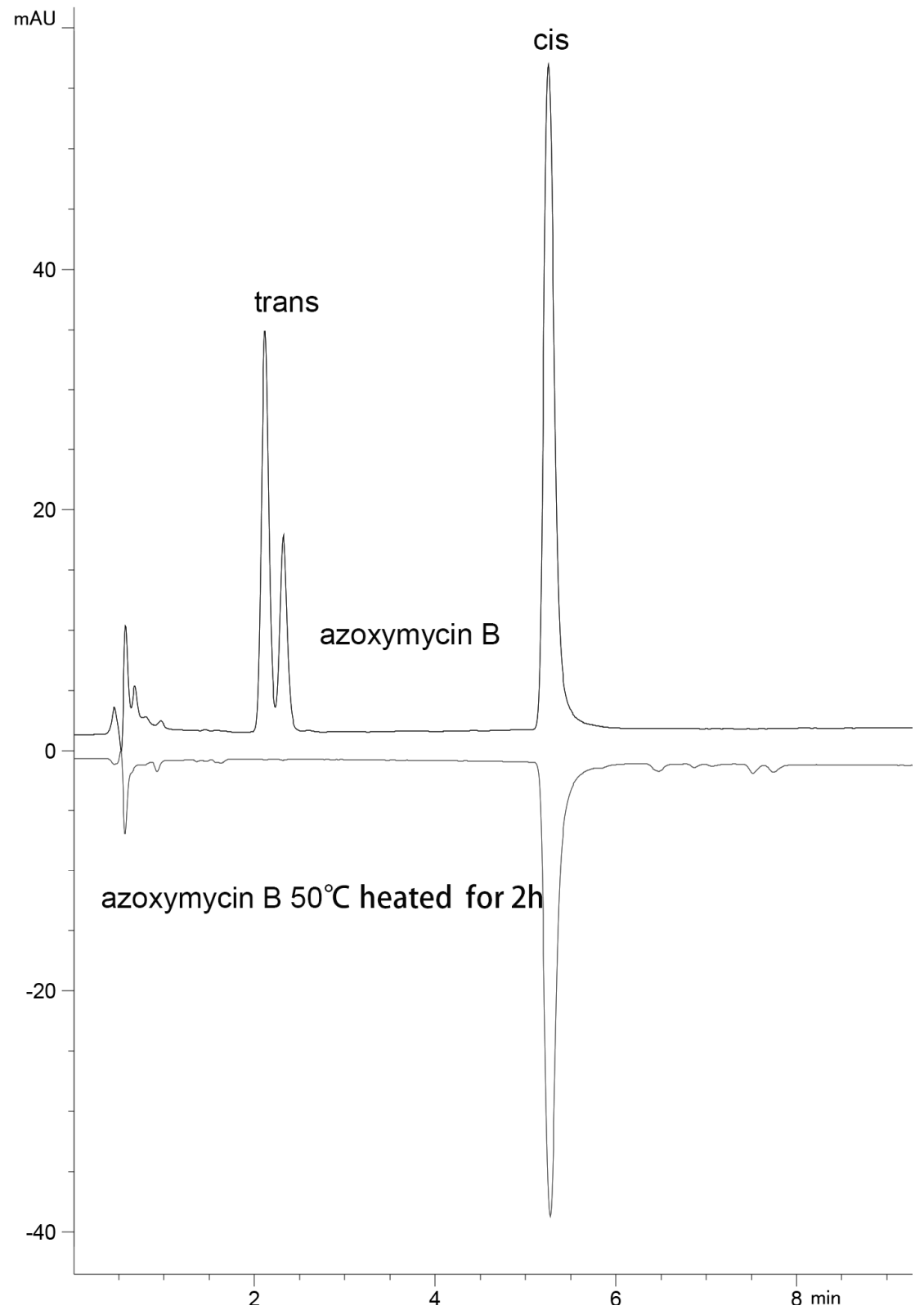

Figure S37. Heat induced trans-cis isomerization of azoxymycin B. 


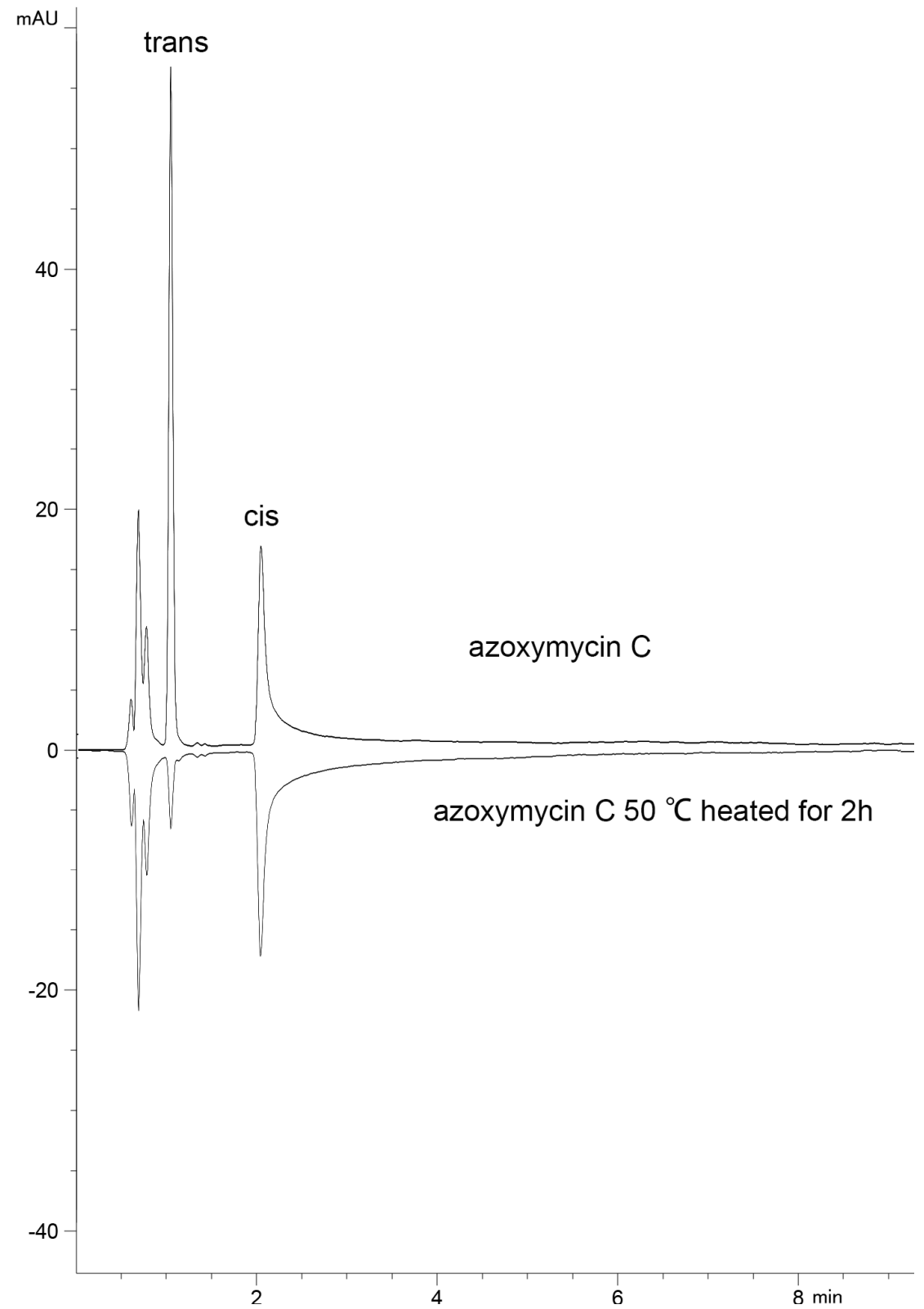

Figure S38. Heat induced trans-cis isomerization of azoxymycin C. 


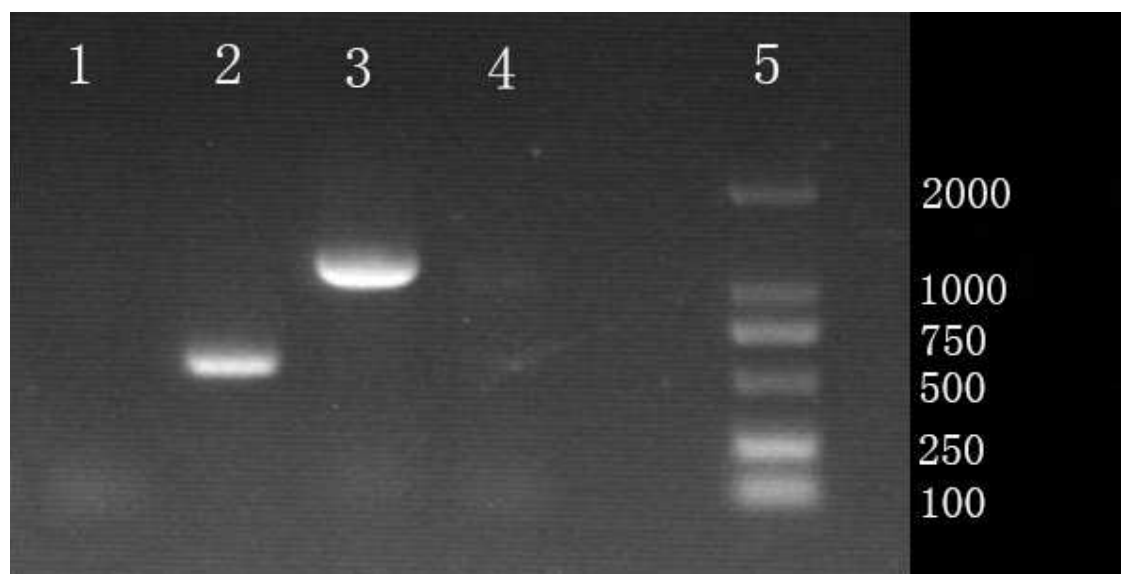

Figure S39. PCR test of the $\triangle a z o C:: a a c(3) I V .1$ was the PCR result of mutant strain with GYY11/GYY12 primers, 2 was that of wild type strain with GYY11/GYY12 primers, 3 was that of mutant strain with GYY17/GYY18, 4 was that of wild type strain with GYY17/GYY18.

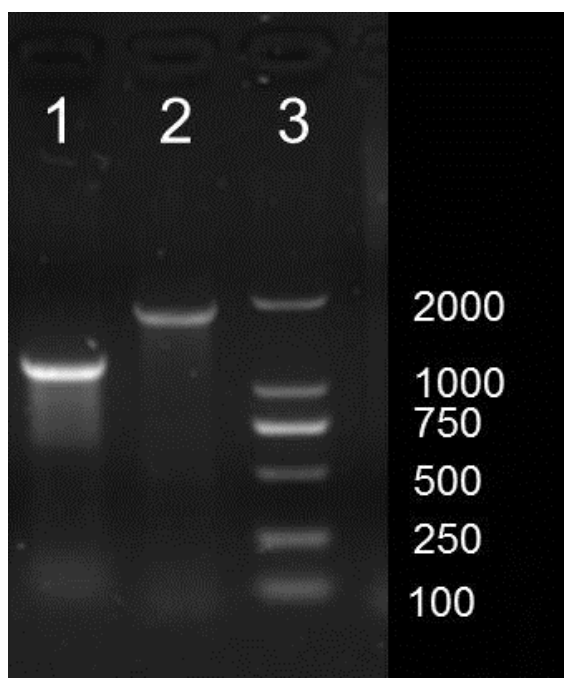

Figure S40. PCR test of the $\triangle a z o F G: a a c(3) I V .1$ was the PCR result of mutant strain with GYY19/GYY20 primers, 2 was that of wild type strain with GYY19/GYY20 primers. 


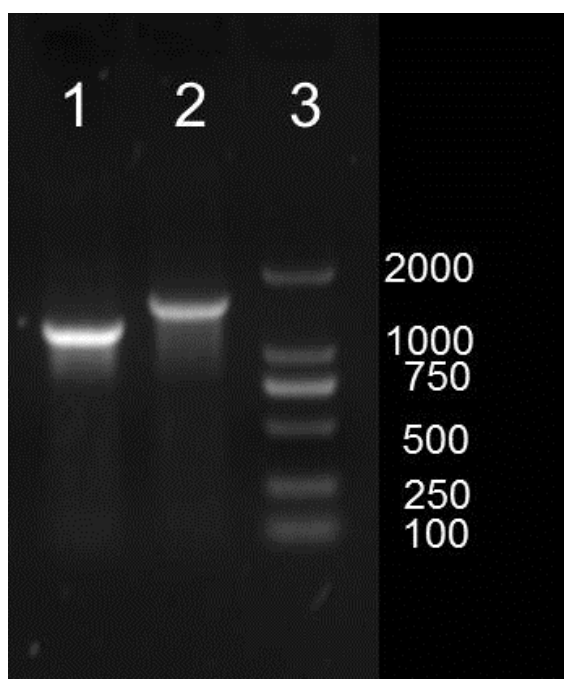

Figure S41. PCR test of the $\triangle a z o J:: a a c(3) I V .1$ was the PCR result of mutant strain with GYY21/GYY22 primers, 2 was that of wild type strain with GYY21/GYY22 primers. 

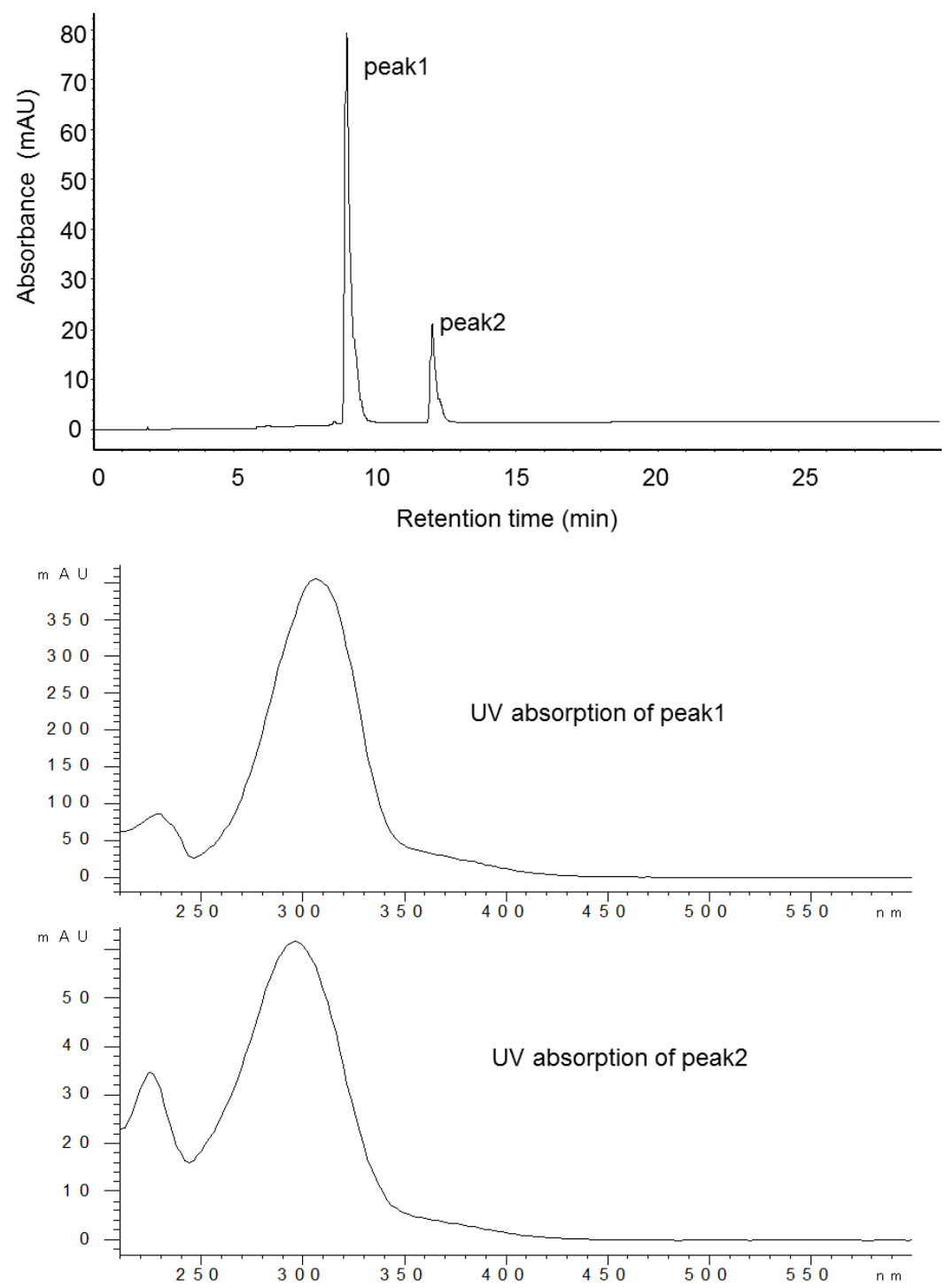

Figure S42. HPLC Split and UV/Vis absorption of compound A 

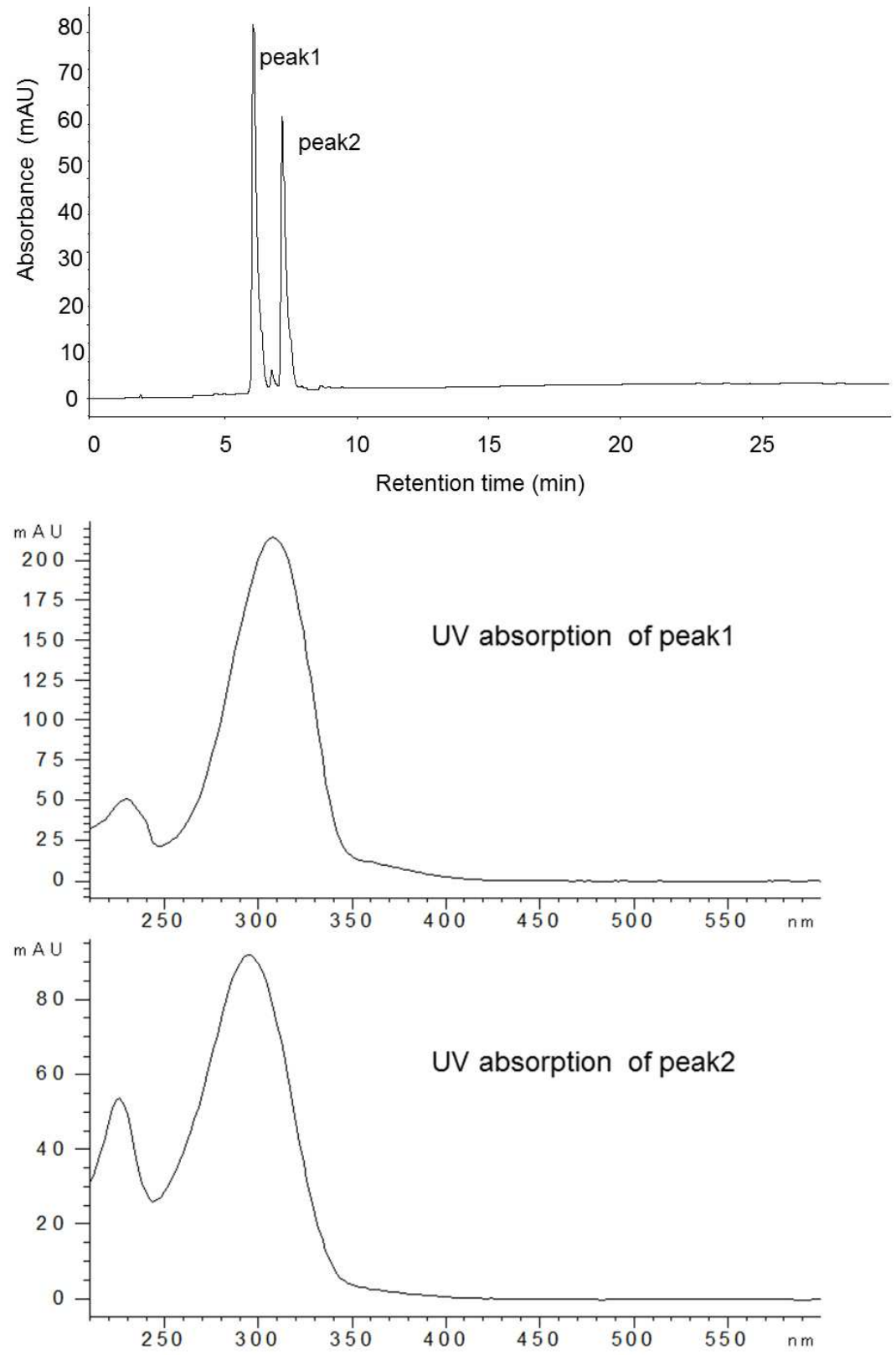

Figure S43. HPLC Split and UV absorption of compound B. 


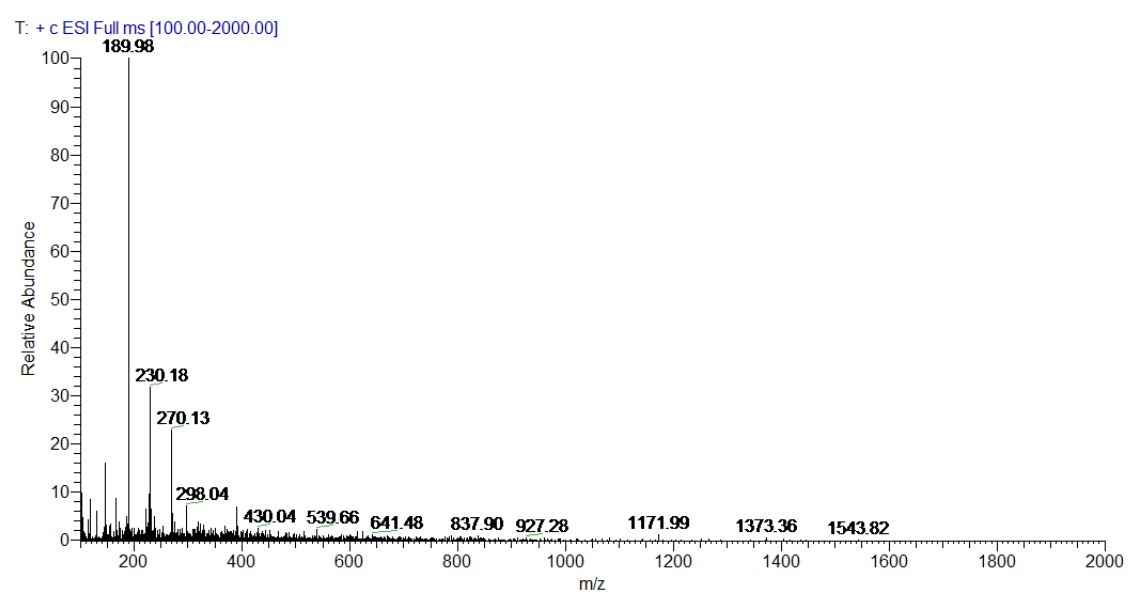

Figure S44. MS of compound A.

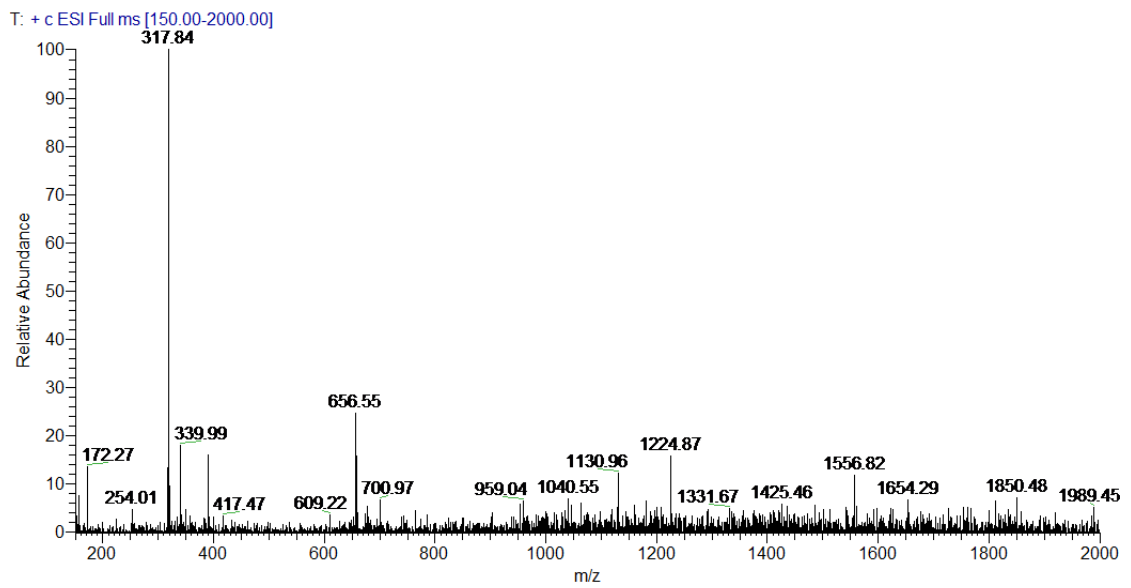

Figure S45. MS of compound B. 